\title{
The sensory cilia of Caenorhabditis elegans*
}

Peter N. Inglis ${ }^{1}$, Guangshuo $\mathrm{Ou}^{2}$, Michel R. Leroux ${ }^{1 \S}$, and Jonathan M. Scholey ${ }^{2}$

${ }^{1}$ Department of Molecular Biology and Biochemistry, Simon Fraser University, Burnaby, BC Canada V5A 1 S6

${ }^{2}$ Center of Genetics and Development, University of California at Davis, Davis, CA 95616 USA

\section{Table of Contents}

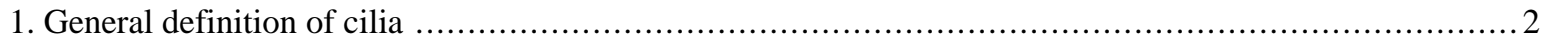

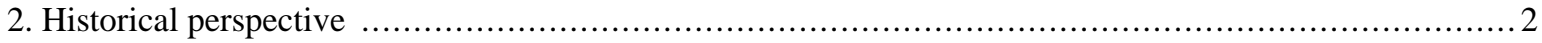

3. C. elegans cilia: distribution and architecture .............................................................. 2

3.1. Amphids/Phasmids ......................................................................... 3

3.2. Inner/outer labial, cephalic neurons ....................................................... 4

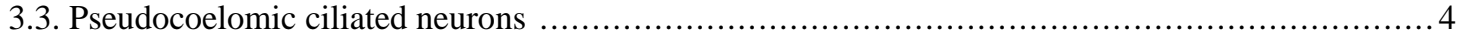

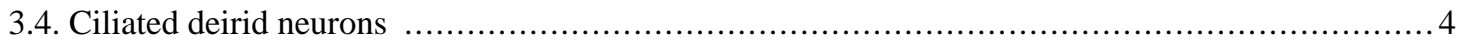

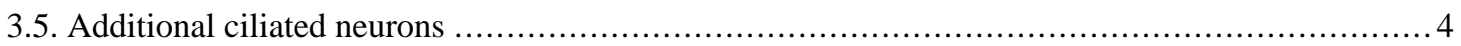

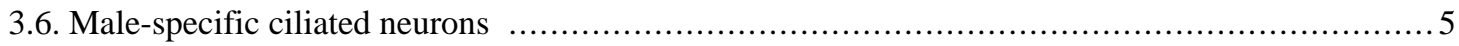

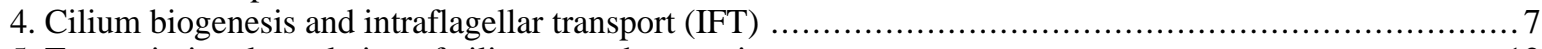

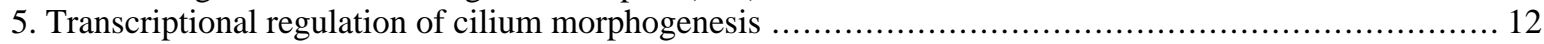

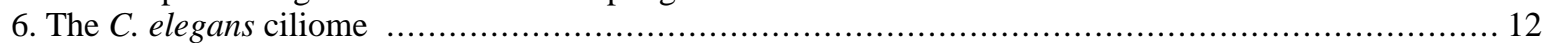

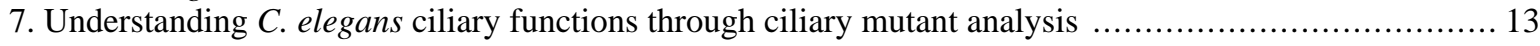

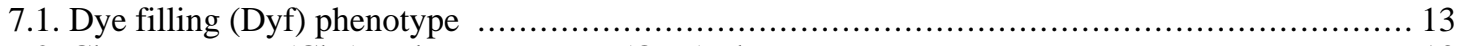

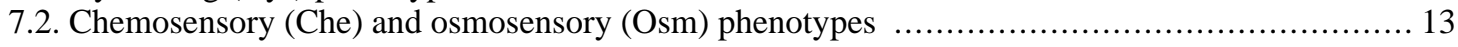

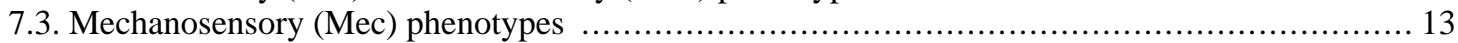

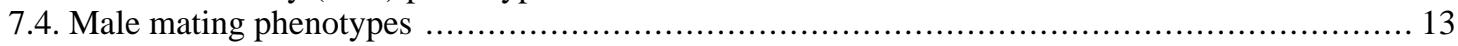

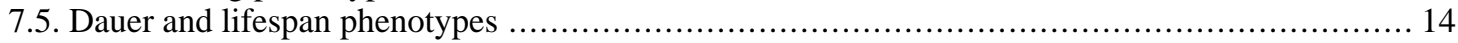

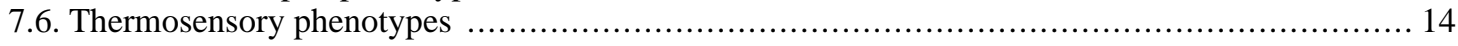

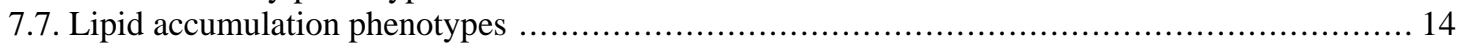

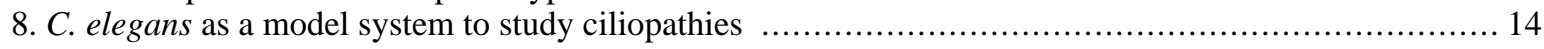

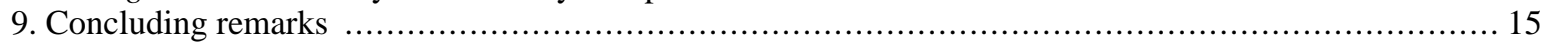

*Edited by James M. Kramer and Donald G. Moerman. Last revised November 22, 2006. Published November 27, 2006. This chapter should be cited as: Inglis P.N. et al. The sensory cilia of Caenorhabditis elegans (November 27, 2006), WormBook, ed. The C. elegans Research Community, WormBook, doi/10.1895/wormbook.1.126.1, http://www.wormbook.org.

Copyright: ( 2006 Inglis, P.N. et al. This is an open-access article distributed under the terms of the Creative Commons Attribution License, which permits unrestricted use, distribution, and reproduction in any medium, provided the original author and source are credited.

${ }^{\S}$ To whom correspondence should be addressed. E-mail: leroux @ sfu.ca 


\begin{abstract}
The non-motile cilium, once believed to be a vestigial cellular structure, is now increasingly associated with the ability of a wide variety of cells and organisms to sense their chemical and physical environments. With its limited number of sensory cilia and diverse behavioral repertoire, $C$. elegans has emerged as a powerful experimental system for studying how cilia are formed, function, and ultimately modulate complex behaviors. Here, we discuss the biogenesis, distribution, structures, composition and general functions of $C$. elegans cilia. We also briefly highlight how $C$. elegans is being used to provide molecular insights into various human ciliopathies, including Polycystic Kidney Disease and Bardet-Biedl Syndrome.
\end{abstract}

\title{
1. General definition of cilia
}

Cilia are slender microtubule-based subcellular organelles that emanate from the cell surfaces of virtually all eukaryotic organisms. Two types of cilia exist: motile cilia (alternatively termed flagella), which are used for locomotion or for the generation of fluid flow, and non-motile (primary) cilia, which are implicated in sensing the chemical and/or physical extracellular environments. Eukaryotic cilia are evolutionarily distinct from the similarly-shaped microvilli or stereocilia that are built from an actin cytoskeleton, and from the bacterial flagellum that drives motility in some prokaryotes.

\section{Historical perspective}

In a letter to Max Perutz dated June 5, 1963, Sydney Brenner wrote that a key unresolved question in biology was how the nervous system developed, and proposed that another important area of research could be how multicellular organisms controlled flagellation and ciliation (http://elegans.swmed.edu/Sydney.html). Fittingly, many of the early studies on $C$. elegans were centered on its chemotactic behaviors, which we now understand depend on the functions of cilia present in sensory neurons, and some of the earliest mutants to be isolated were defective in their abilities to sense environmental conditions (Ward, 1973; Dusenbery, 1974; Dusenbery et al., 1975). Although at that time the link between chemosensation and cilia was not firmly established, electron microscopic reconstruction of the environmentally-exposed, cilia-based sensory system at the anterior end of the animal helped to make the link more evident (Ward et al., 1975; Ware et al., 1975).

\section{C. elegans cilia: distribution and architecture}

Unlike many organisms, including humans, the only ciliated cell type in C. elegans is the sensory neuron, and none of the cilia in the nematode are motile. Of the 302 neurons found in the adult hermaphrodite, a substantial number (60) possess cilia at the ends of their dendritic processes.

Cilia from all studied organisms are known to nucleate from a modified centriolar structure termed a 'basal body'. Most often, the basal body is positioned in proximity to the cellular membrane from where the cilium emanates. C. elegans basal bodies have been described as more 'degenerate' and termed 'transition zones' by Perkins et al. (1986). Ultrastructurally, the $C$. elegans transition zone (also termed 'proximal segment') typically possesses a circular array of doublet microtubules (as opposed to the triplet microtubule arrangement most often associated with basal bodies in other organisms). In amphid and phasmid cilia, the transition zone is followed by a so-called 'middle segment' characterized by a canonical arrangement of 9 doublet microtubules, and this middle segment transforms into a 'distal segment' built of singlet microtubules (Figure 1); notably, in some ciliated neurons, these ultrastructural features may be somewhat divergent (Ward et al., 1975; Ware et al., 1975; Perkins et al., 1986). Additional singlet microtubules are often present in the central region of the C. elegans cilia (Figure 1), but these microtubules are likely distinct from the central pairs observed in motile cilia. On the whole, this organization of doublets transitioning to singlets at the distal end is very similar to that seen in the flagella of mating Chlamydomonas cells (Mesland et al., 1980) and may be a general property of sensory cilia, as it has also been observed in several vertebrate cell types (e.g., pancreatic, renal and olfactory cells; Reese 1965; Webber and Lee, 1975; Hidaka et al., 1995). The nature and positions of the $C$. elegans ciliated cell bodies and of representative dendritic ciliated endings are shown schematically in Figure 1. 

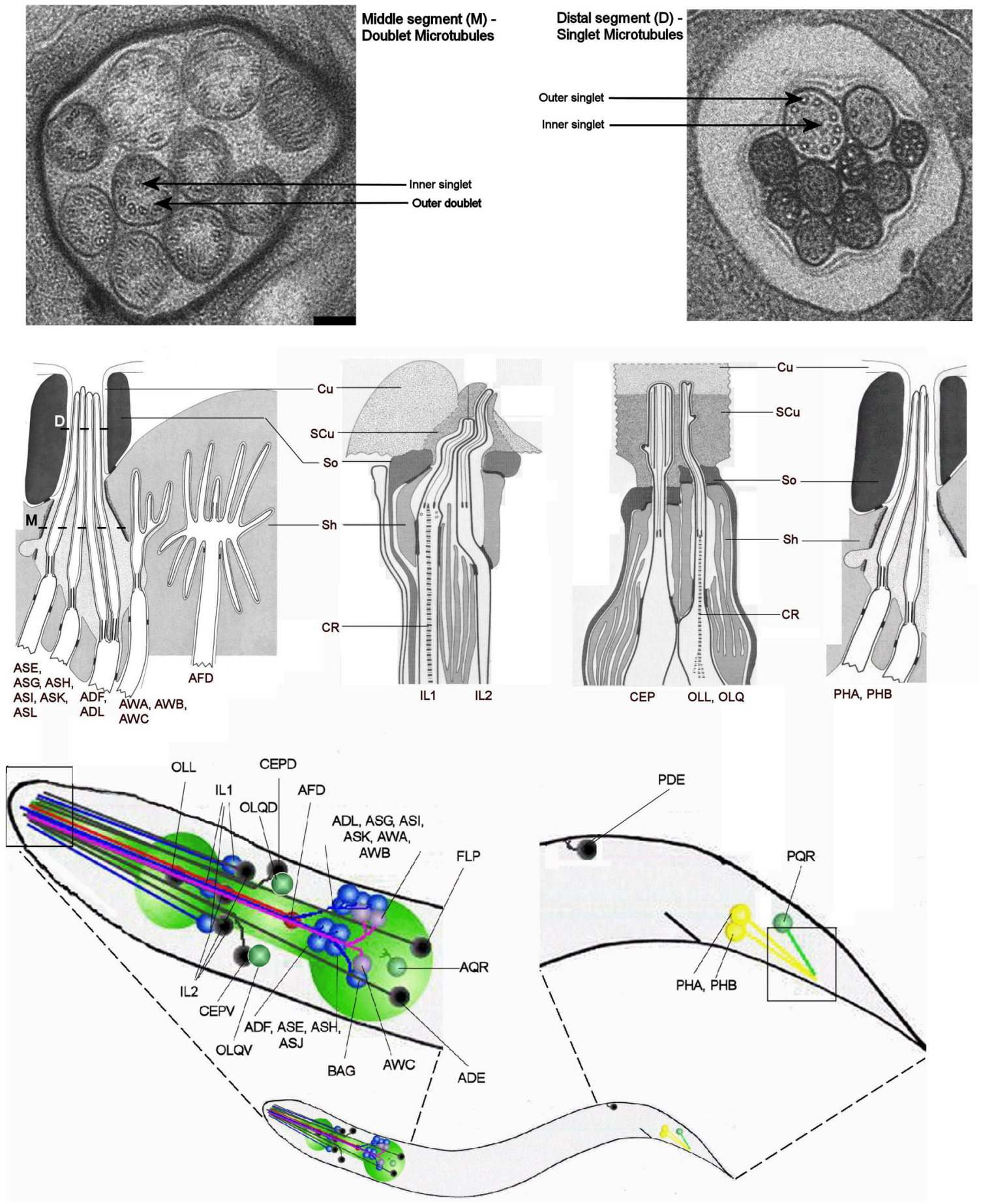

Figure 1. Ultrastructures of cilia and relative positions of all known ciliated neurons (cell bodies and associated dendrites) in the $C$. elegans hermaphrodite. The top two panels show electron micrograph cross-sections of amphid cilia in the middle segment (microtubule doublets; left panel) and distal segment (microtubule singlets; right panel; adapted from Evans et al., 2006). The worm figures illustrate the positions of the all ciliated cell bodies and their dendritic extensions. The four insets show, schematically, electron micrograph reconstructions of known ciliated endings (adapted from Perkins et al. (1986) for amphids and phasmids and Ward et al. (1975) for labial and cephalic neurons). Cu, cuticle; CR, ciliary rootlet; SCu, subcuticle; So, socket cell; Sh, sheath cell

\subsection{Amphids/Phasmids}

The primary chemosensory organ of $C$. elegans is built from a collection of amphid neurons whose cell bodies are located in the anterior region of the pharyngeal bulb and possess axons that associate with the nerve ring. The 
dendrites of these neurons extend to the anterior end of the animal and terminate with diverse ciliated structures (Figure 1). The proximal regions of amphid cilia are typically protected by a sheath cell and extend through a channel created by socket cells to become partially exposed to the external environment. The majority of amphid neurons possess cilia shaped as single rods (ASE, ASG, ASH, ASI, ASJ, ASK) or pairs of rods (ADF, ADL). Other amphids boast cilia that have membrane elaborations and possess unusual shapes; these are the wing neurons (AWA, AWB, AWC) and the amphid finger neuron (AFD), in which a small cilium is surrounded by approximately 50 villi. Both the wing and AFD neuron cilia terminate within a sheath cell, and thus are not exposed to the external environment. The lengths of amphid cilia range from 7.5 $\mu$ m (in the ASE, ASG, ASH, ASI, ASJ and ASK neurons) to $\sim 1.5 \mu \mathrm{m}$ for the AFD cilium (Ward et al., 1975; Ware et al., 1975; Perkins et al., 1986). Similar in structure to the single rod-like cilia found in amphids are the PHA and PHB phasmid cilia. These are located slightly posterior to the anus of the worm and are exposed to the external environment (Hall and Russell, 1991).

\subsection{Inner/outer labial, cephalic neurons}

The inner labial neuron types (IL1, IL2) are both arranged symmetrically in sets of 6 cells, ultimately terminating in the 6 "lips" that surround the mouth of the worm. Originating from a position anterior to the amphids, the dendrites of these neurons terminate in shorter cilia, and possess a seemingly more degenerate basal body. While the IL1 cilia consistently originate from basal bodies consisting of 7 doublet microtubules, those of IL2 neurons are more variable (ranging from 5-7 doublets). These neurons are further distinguished by the fact that, while the IL1 cilia ultimately terminate, or embed, in the subcuticle, the IL2 cilia are exposed to the external environment via openings in the cuticle (Ward et al., 1975; Ware et al., 1975).

The outer labial (2 lateral outer labial, or OLL neurons, and 4 quadrant outer labial, or OLQ neurons) and cephalic (CEP; 4 neurons) neurons similarly terminate, albeit in a more restricted fashion, in the cuticle near the sub-dorsal, sub-ventral, and lateral lips of $C$. elegans. The cilia found at the dendritic termini of CEP neurons possess a degenerate transition zone (6-8 doublet microtubules), while those found in the OLL/OLQ neurons have a canonical, 9 microtubule doublet arrangement. The cilia of CEP neurons are unusual in that, $\sim 1 \mu \mathrm{m}$ from the basal body (within the subcuticle), the axonemal microtubules associate with additional microtubules, generating an electron-dense structure difficult to reconstruct via EM (Ward et al., 1975; Ware et al., 1975).

Interestingly, the IL1, OLL and OLQ neurons are unique in the fact that they have striated rootlet structures descending from their transition zones (WormAtlas; Ward et al., 1975; Ware et al., 1975). Ciliary rootlets are prominent fibrous polymers of the protein rootletin that emanate from the proximal end of the basal body (Yang et al., 2002). Rootlets have been implicated in the maintenance and longevity of vertebrate sensory cilia (Yang et al., 2005), as well as in providing scaffolding for kinesin-1-based intracellular transport (Yang and Li, 2005). It should be noted that very little is known about the rootlets of $C$. elegans; even a rootletin homolog has yet to be clearly identified.

\subsection{Pseudocoelomic ciliated neurons}

Two unusual ciliated cell types, AQR (located near the pharynx) and PQR (found posterior to the phasmids in the tail), are found, along with their cilia, to be directly exposed to the pseudocoelomic cavity of the worm. Extremely little is known about the ultrastructure of the cilia of these neurons, although they can be identified under a compound microscope using, for example, the GCY-36 protein fused to GFP (Cheung et al. 2004).

\subsection{Ciliated deirid neurons}

The 4 lateral, cervical deirid neurons are found in pairs, at the posterior end of the pharyngeal bulb (ADE) and slightly anterior to the anus (PDE). Like many of the other neurons discussed in this review, their ciliated dendritic endings are in a channel formed by a socket cell and an invaginated sheath cell. The cilia of both ADE and PDE terminate in the subcuticle, and thus are not exposed to the external environment. These ADE/PDE cilia are remarkably similar to those found in the 4 CEP neurons, and, interestingly, these 8 neurons constitute the complete dopaminergic neuron set for the hermaphrodite worm (Sulston and Brenner, 1975; Ward et al., 1975; Ware et al., 1975).

\subsection{Additional ciliated neurons}

BAG and FLP are two relatively uncharacterized ciliated neurons whose cilia both terminate in or near the lateral lips of the worm. Unlike many of the other neurons described in this review, their cilia are not surrounded by 
support cells. Furthermore, their ultrastructures are quite complex, appearing via EM reconstruction as "bags" (BAG) or “flaps" (FLP) (Ward et al., 1975; Ware et al., 1975; Perkins et al., 1986).

\subsection{Male-specific ciliated neurons}

C. elegans males have 52 additional ciliated sensory neurons, the majority of which are found in the male tail rays/hooks, where the cilia perform sensory functions (Peden and Barr 2005). It should be noted, however, that only 48 of these 52 neurons are confirmed by EM to have cilia (Sulston et al., 1980). General descriptions of the structure and function of male-specific cilia are described in Table 1. While in many organisms spermatozoa possess motile cilia (flagella), those of $C$. elegans are aflagellar, relying on amoeboid locomotion to reach and fertilize oocytes (Nelson et al., 1982).

Table 1. Description of individual ciliated neuron types and their reported functions

\begin{tabular}{|c|c|c|c|c|c|c|}
\hline $\begin{array}{l}\text { Ciliated } \\
\text { neuron }\end{array}$ & $\begin{array}{c}\text { Cilium } \\
\text { structure }\end{array}$ & Exposed? & Embedded? & Dye fills? & General role & Reference(s) \\
\hline ASE (L/R) & Single rod & $\mathrm{Y}$ & & & Chemoattraction & $\begin{array}{l}\text { Ward et al. 1975; } \\
\text { Ware et al. 1975; } \\
\text { Perkins et al. } 1986\end{array}$ \\
\hline $\mathrm{ADF}(\mathrm{L} / \mathrm{R})$ & Pair of rods & $\mathrm{Y}$ & & FITC, DiI & Dauer entry & $\begin{array}{l}\text { Ward et al. 1975; } \\
\text { Ware et al. 1975; } \\
\text { Perkins et al. } 1986\end{array}$ \\
\hline $\mathrm{ASG}(\mathrm{L} / \mathrm{R})$ & Single rod & $\mathrm{Y}$ & & & Chemoattraction & $\begin{array}{l}\text { Ward et al. } 1975 ; \\
\text { Ware et al. } 1975 ; \\
\text { Perkins et al. } 1986\end{array}$ \\
\hline ASH (L/R) & Single rod & $\mathrm{Y}$ & & FITC, DiI & $\begin{array}{l}\text { Mechanosensory } \\
\text { (Nose touch), } \\
\text { chemorepulsion, } \\
\text { osmo-avoidance }\end{array}$ & $\begin{array}{l}\text { Ward et al. 1975; } \\
\text { Ware et al. 1975; } \\
\text { Perkins et al. } \\
\text { 1986; Kaplan and } \\
\text { Horvitz, } 1993\end{array}$ \\
\hline ASI (L/R) & Single rod & $\mathrm{Y}$ & & FITC, DiI & Chemoattraction & $\begin{array}{l}\text { Ward et al. 1975; } \\
\text { Ware et al. 1975; } \\
\text { Perkins et al. } 1986\end{array}$ \\
\hline ASJ (L/R) & Single rod & $Y$ & & FITC, DiI & $\begin{array}{c}\text { Dauer } \\
\text { exit/recovery }\end{array}$ & $\begin{array}{l}\text { Ward et al. } 1975 ; \\
\text { Ware et al. } 1975 ; \\
\text { Perkins et al. } 1986\end{array}$ \\
\hline ASK (L/R) & Single rod & $\mathrm{Y}$ & & FITC, DiI & Chemoattraction & $\begin{array}{l}\text { Ward et al. } 1975 ; \\
\text { Ware et al. } 1975 ; \\
\text { Perkins et al. } 1986\end{array}$ \\
\hline $\mathrm{ADL}(\mathrm{L} / \mathrm{R})$ & Pair of rods & $\mathrm{Y}$ & & FITC, DiI & Chemorepulsion & $\begin{array}{l}\text { Ward et al. } 1975 ; \\
\text { Ware et al. } 1975 ; \\
\text { Perkins et al. } 1986\end{array}$ \\
\hline $\begin{array}{l}\text { AWA } \\
(\mathrm{L} / \mathrm{R})\end{array}$ & Winged & $\mathrm{N}$ & Sheath cell & & Chemoattraction & $\begin{array}{l}\text { Ward et al. } 1975 ; \\
\text { Ware et al. } 1975 ; \\
\text { Perkins et al. } 1986\end{array}$ \\
\hline $\begin{array}{l}\text { AWB } \\
(\mathrm{L} / \mathrm{R})\end{array}$ & Winged & $\mathrm{N}$ & Sheath cell & & Chemorepulsion & $\begin{array}{l}\text { Ward et al. } 1975 ; \\
\text { Ware et al. } 1975 ; \\
\text { Perkins et al. } 1986\end{array}$ \\
\hline $\begin{array}{l}\text { AWC } \\
(\mathrm{L} / \mathrm{R})\end{array}$ & Winged & $\mathrm{N}$ & Sheath cell & & Chemoattraction & $\begin{array}{l}\text { Ward et al. 1975; } \\
\text { Ware et al. 1975; } \\
\text { Perkins et al. } 1986\end{array}$ \\
\hline AFD (L/R) & $\begin{array}{c}\text { Small, } \\
\text { surrounded by } \\
\text { dendritic villi }\end{array}$ & $\mathrm{N}$ & Sheath cell & & Thermosensation & $\begin{array}{l}\text { Ward et al. } 1975 ; \\
\text { Ware et al. } 1975 ; \\
\text { Perkins et al. } 1986\end{array}$ \\
\hline
\end{tabular}




\begin{tabular}{|c|c|c|c|c|c|c|}
\hline $\begin{array}{l}\text { Ciliated } \\
\text { neuron }\end{array}$ & $\begin{array}{c}\text { Cilium } \\
\text { structure }\end{array}$ & Exposed? & Embedded? & Dye fills? & General role & Reference(s) \\
\hline $\begin{array}{c}\mathrm{IL} 1 \\
(\mathrm{DL} / \mathrm{DR} / \\
\mathrm{L} / \mathrm{R} / \mathrm{VL} / \mathrm{V})\end{array}$ & & $\mathrm{N}$ & Subcuticle & & $\begin{array}{l}\text { Mechanosensation } \\
\text { (Nose touch) }\end{array}$ & $\begin{array}{l}\text { Ward et al. 1975; } \\
\text { Ware et al. 1975; } \\
\text { Perkins et al. } \\
\text { 1986; Hart et al., } \\
1995\end{array}$ \\
\hline $\begin{array}{c}\text { IL2 } \\
(\mathrm{DL} / \mathrm{DR} / \\
\mathrm{L} / \mathrm{R} / \mathrm{VL} / \mathrm{V})\end{array}$ & & $\mathrm{Y}$ & & DiI, DiO & $\begin{array}{c}\text { Unknown } \\
\text { (presumably } \\
\text { chemosensory) }\end{array}$ & $\begin{array}{l}\text { Ward et al. 1975; } \\
\text { Ware et al. 1975; } \\
\text { Perkins et al. } 1986\end{array}$ \\
\hline $\begin{array}{c}\mathrm{CEP} \\
\text { (DL/DR/ } \\
\mathrm{VL} / \mathrm{VR})\end{array}$ & & $\mathrm{N}$ & Cuticle & $\begin{array}{c}\text { FITC } \\
\text { (occasionally) }\end{array}$ & $\begin{array}{c}\text { Mechanosensation } \\
\text { (Basal slowing } \\
\text { response) }\end{array}$ & $\begin{array}{l}\text { Ward et al. 1975; } \\
\text { Ware et al. 1975; }\end{array}$ \\
\hline $\begin{array}{c}\text { OLQ } \\
(\mathrm{DL} / \mathrm{DR} / \\
\mathrm{VL} / \mathrm{VR})\end{array}$ & & $\mathrm{N}$ & Cuticle & & $\begin{array}{l}\text { Mechanosensation } \\
\text { (Nose touch and } \\
\text { basal slowing } \\
\text { response) }\end{array}$ & $\begin{array}{l}\text { Ward et al. 1975; } \\
\text { Ware et al. 1975; } \\
\text { Perkins et al. } \\
\text { 1986; Kaplan and } \\
\text { Horvitz, 1993; }\end{array}$ \\
\hline OLL (L/R) & & $\mathrm{N}$ & Cuticle & & $\begin{array}{c}\text { Mechanosensation } \\
\text { (putative) }\end{array}$ & $\begin{array}{l}\text { Ward et al. 1975; } \\
\text { Ware et al. 1975; } \\
\text { Perkins et al. } 1986\end{array}$ \\
\hline $\mathrm{BAG}(\mathrm{L} / \mathrm{R})$ & & $\mathrm{N}$ & $\begin{array}{l}\text { Behind } \\
\text { cuticle }\end{array}$ & & Unknown & Perkins et al. 1986 \\
\hline FLP (L/R) & & $\mathrm{N}$ & $\begin{array}{l}\text { Behind } \\
\text { cuticle }\end{array}$ & & $\begin{array}{c}\text { Mechanosensation } \\
\text { (Nose touch) }\end{array}$ & $\begin{array}{l}\text { Perkins et al. } \\
\text { 1986; Kaplan and } \\
\text { Horvitz, } 1993\end{array}$ \\
\hline $\mathrm{ADE}(\mathrm{L} / \mathrm{R})$ & Single rod & $\mathrm{N}$ & Subcuticle & $\begin{array}{c}\text { FITC } \\
\text { (occasionally) }\end{array}$ & $\begin{array}{l}\text { Mechanosensation } \\
\text { (Basal slowing } \\
\text { response) }\end{array}$ & $\begin{array}{l}\text { Ward et al. 1975; } \\
\text { Ware et al. 1975; } \\
\text { Perkins et al. } \\
\text { 1986; Sulston and } \\
\text { Brenner, 1975 }\end{array}$ \\
\hline $\mathrm{PDE}(\mathrm{L} / \mathrm{R})$ & Single rod & $\mathrm{N}$ & Subcuticle & $\begin{array}{c}\text { FITC } \\
\text { (occasionally) }\end{array}$ & $\begin{array}{c}\text { Mechanosensation } \\
\text { (Basal slowing } \\
\text { response) }\end{array}$ & $\begin{array}{l}\text { Ward et al. 1975; } \\
\text { Ware et al. 1975; } \\
\text { Perkins et al. } \\
\text { 1986; Sulston and } \\
\text { Brenner, 1975 }\end{array}$ \\
\hline PHA (L/R) & Single rod & $\mathrm{Y}$ & & FITC, DiI & Chemorepulsion & $\begin{array}{l}\text { Hall and Russell, } \\
1991\end{array}$ \\
\hline PHB (L/R) & Single rod & $\mathrm{Y}$ & & FITC, DiI & Chemorepulsion & $\begin{array}{l}\text { Hall and Russell, } \\
1991\end{array}$ \\
\hline $\mathrm{AQR}$ & & $\begin{array}{c}\mathrm{Y} \\
\text { (pseudocoelom) }\end{array}$ & & & $\begin{array}{c}\text { Oxygen-sensation, } \\
\text { social feeding } \\
\end{array}$ & $\begin{array}{l}\text { Cheung et al., } \\
2005\end{array}$ \\
\hline PQR & & $\begin{array}{c}\mathrm{Y} \\
\text { (pseudocoelom) }\end{array}$ & & & $\begin{array}{l}\text { Oxygen-sensation, } \\
\text { social feeding }\end{array}$ & $\begin{array}{l}\text { Hall and Russell, } \\
\text { 1991; Cheung et } \\
\text { al., } 2005\end{array}$ \\
\hline \multicolumn{7}{|c|}{ Male-specific ciliated neurons } \\
\hline $\begin{array}{c}\text { CEM } \\
\text { (DL/DR/ } \\
\text { VL/VR) } \\
\end{array}$ & & $\mathrm{Y}$ & & & $\begin{array}{l}\text { Male chemotaxis } \\
\text { (putative) }\end{array}$ & Sulston et al. 1980 \\
\hline $\begin{array}{c}\mathrm{RnA}(\mathrm{L} / \mathrm{R}) \\
(\mathrm{n}=1-9)\end{array}$ & & $\mathrm{N}$ & $\begin{array}{l}\text { structural } \\
\text { cell }\end{array}$ & rarely & $\begin{array}{c}\text { Male mating } \\
\text { behavior }\end{array}$ & Sulston et al. 1980 \\
\hline $\mathrm{RnB}(\mathrm{L} / \mathrm{R})$ & & Y (not R6B) & & rarely & Male mating & Sulston et al. 1980 \\
\hline
\end{tabular}




\begin{tabular}{|c|c|c|c|c|c|l|}
\hline $\begin{array}{c}\text { Ciliated } \\
\text { neuron }\end{array}$ & $\begin{array}{c}\text { Cilium } \\
\text { structure }\end{array}$ & Exposed? & Embedded? & Dye fills? & General role & Reference(s) \\
\hline$(\mathrm{n}=1-9)$ & & & & & behavior & \\
\hline HOA & & $\mathrm{N}$ & subcuticle & & $\begin{array}{c}\text { Sensing vulva in } \\
\text { male-mating } \\
\text { behavior }\end{array}$ & Sulston et al. 1980 \\
\hline HOB & & Y & & & $\begin{array}{c}\text { Sensing vulva in } \\
\text { male-mating } \\
\text { behavior }\end{array}$ & Sulston et al. 1980 \\
\hline PCA (L/R) & & N & & & $\begin{array}{c}\text { Sensing vulva, } \\
\text { inducing spicule } \\
\text { prodding behavior }\end{array}$ & Sulston et al. 1980 \\
\hline SPD (L/R) & & Y & & & Sperm transfer & Sulston et al. 1980 \\
\hline SPV (L/R) & & Y & & & Sperm transfer & Sulston et al. 1980 \\
\hline
\end{tabular}

\section{Cilium biogenesis and intraflagellar transport (IFT)}

Ciliogenesis depends on the intraflagellar transport (IFT) of ciliary precursors from the transition zone, which sits at the junction between the dendrite of the sensory neuron and the cilium, to the growing ciliary structure (Figure 2). The many known components of the IFT machinery, some of which were first identified in C. elegans (Scholey et al. 2004 and see below) are listed in Table 2. Using time-lapse microscopy it has been shown that in $C$. elegans, two IFT motors of the kinesin-2 family, heterotrimeric kinesin-II and homodimeric OSM-3, move IFT-particles (consisting of two multi-protein subcomplexes, A and B; Cole et al., 1998) and presumably ciliary precursor proteins from the base of cilium to their sites of incorporation; this anterograde IFT-machinery, and probably also turnover products, are then transported back to the base of the cilium using the IFT-dynein motor (Movie 1; Figure 2; Orozco et al., 1999; Signor et al., 1999b; Snow et al., 2004). These two anterograde motors cooperate to build the middle and distal segments of cilia. In the middle segment, kinesin-II and OSM-3-kinesin function redundantly to move the same IFT-particles and to assemble the middle segment of the axoneme. In this segment, the slower-moving kinesin-II $\left(0.5 \mu \mathrm{m} \mathrm{s}^{-1}\right)$ reduces the speed of the faster-moving OSM-3 $\left(\sim 1.3 \mu \mathrm{m} \mathrm{s}^{-1}\right)$ to give rise to the intermediate rate of motor-IFT-particle transport observed $\left(\sim 0.7 \mu \mathrm{m} \mathrm{s}^{-1}\right)$. Subsequently, at the middle-distal segment boundary, kinesin-II returns to the base of the cilium, liberating OSM-3, which now moves IFT-particles and bound cargo to the distal tip at its own faster velocity to extend the distal singlets of the axoneme (Snow et al., 2004; Figure 2). Thus, animals lacking functional kinesin-II (e.g., kap-11 mutants) build a full-length cilium due to the redundant function of OSM-3, osm-3 mutants specifically lack the distal segment, and osm-3; kap-1 double mutants fail to make cilia because of the absence of functional Kinesin-II or OSM-3 (Snow et al., 2004). It should be noted that OSM-3 alone specifically extends distal singlets on some axonemes, but not others (Evans et al., 2006). An additional kinesin, KLP-6, has been implicated in male mating behavior and is required for proper localization of the human polycystin-2 homolog, PKD-2, to the cilium (Peden and Barr, 2005). This finding indicates that additional kinesin motors might be involved in ciliary transport, although intriguingly, IFT-like movement of the KLP-6 kinesin was not observed.

Table 2. Components and available mutants of the intraflagellar transport machinery

\begin{tabular}{|c|c|c|c|c|l|}
\hline Component & Gene model & Protein & Description/function & Mutants & Reference \\
\hline \multirow{3}{*}{ Kinesin-II } & F20C5.2 & KLP-11 & 95KD Motor & $t m 324$ & Signor et al. 1999b \\
\cline { 2 - 6 } & Y50D7A.6 & KLP-20 & 85KD Motor & & \\
\cline { 2 - 6 } & F08F8.3 & KAP-1 & Accessory subunit & $o k 676$ & Signor et al. 1999b \\
\hline OSM-3-kinesin & M02B7.3 & OSM-3 & Motor & $p 802$ & Shakir et al., 1993 \\
\hline \multirow{3}{*}{ IFT-dynein } & F18C12.1 & CHE-3 & Motor & $e 1124$ & Wicks et al., 2000 \\
\cline { 2 - 6 } & F02D8.3 & XBX-1 & Light intermediate chain & $o k 279$ & Schafer et al., 2003 \\
\cline { 2 - 6 } & D1009.5 & DYLT-2 & Light chain & tm2097 & Efimenko et al., 2005 \\
\hline
\end{tabular}




\begin{tabular}{|c|c|c|c|c|c|}
\hline Component & Gene model & Protein & Description/function & Mutants & Reference \\
\hline \multirow{5}{*}{$\begin{array}{c}\text { IFT subcomplex } \\
\mathrm{A}^{1}\end{array}$} & C27A7.4 & CHE-11 & IFT140 & el810 & Qin et al., 2001 \\
\hline & Unknown & & IFT139 & & \\
\hline & F23B2.4 & DAF-10 & IFT122A & e1387 & Bell et al., 2006 \\
\hline & Unknown & & IFT122B & & \\
\hline & Unknown & & IFT43 & & \\
\hline \multirow{6}{*}{$\begin{array}{l}\text { IFT subcomplex } \\
\mathrm{B}^{1}(\text { core })\end{array}$} & Y41G9A.1 & OSM-5 & IFT88 & $p 813$ & Haycraft et al., 2001 \\
\hline & F32A6.2 & & IFT81 & & \\
\hline & C18H9.8 & & IFT(74/72) & & \\
\hline & R31.3 & OSM-6 & IFT52 & $p 811$ & Collet et al., 1998 \\
\hline & Unknown & & IFT46 & & \\
\hline & Unknown & & IFT27 & & \\
\hline \multirow{4}{*}{$\begin{array}{l}\text { IFT subcomplex } \\
\mathrm{B}^{1} \text { (periphery) }\end{array}$} & T27B1.1 & OSM-1 & IFT172 & $p 808$ & Bell et al., 2006 \\
\hline & F38G1.1 & CHE-2 & IFT80 & e1033 & Fujiwara et al., 1999 \\
\hline & F59C6.7 & CHE-13 & IFT(57/55) & e1805 & Haycraft et al., 2003 \\
\hline & \begin{tabular}{|l|} 
Y110A7A.20 \\
\end{tabular} & & IFT20 & & \\
\hline \multirow{8}{*}{ BBS proteins } & Y105E8A.5 & BBS-1 & \multirow{8}{*}{$\begin{array}{l}\text { BBS-7 and BBS-8 act to } \\
\text { stabilize IFT subcomplex A } \\
\text { and B components and } \\
\text { join/coordinate the two } \\
\text { kinesin motors, } \\
\text { OSM-3-kinesin and } \\
\text { Kinesin-II }\end{array}$} & ok1111 & Mak et al., 2006 \\
\hline & F20D12.3 & BBS-2 & & & $\begin{array}{l}\text { Efimenko et al., 2005; } \\
\text { Blacque et al., 2005 }\end{array}$ \\
\hline & C38D4.8 & BBS-3 & & & Fan et al., 2004 \\
\hline & F58A4.14 & BBS-4 & & & Unpublished \\
\hline & R01H10.6 & BBS-5 & & & Blacque et al., 2005 \\
\hline & Y75B8A.12 & BBS-7 & & $n 1606$ & Blacque et al., 2004 \\
\hline & T25F10.5 & BBS-8 & & $n x 77$ & Blacque et al., 2004 \\
\hline & C48B6.8 & BBS-9 & & & Blacque et al., 2005 \\
\hline \multirow[b]{2}{*}{ Motor activators } & F54C1.5 & DYF-1 & Activates OSM-3-kinesin & $m n 335$ & Ou et al., 2005 \\
\hline & C27H5.7 & DYF-13 & $\begin{array}{l}\text { Function unclear; required } \\
\text { for building distal segment }\end{array}$ & $m n 396$ & Blacque et al., 2005 \\
\hline \multirow{4}{*}{ Various } & ZK520.1/.3 & DYF-2 & IFT protein & $m 160$ & Efimenko et al., 2006 \\
\hline & C04C3.5 & DYF-3 & IFT protein; linked to PKD & $m 185$ & $\begin{array}{l}\text { Murayama et al., 2005; Ou et } \\
\text { al., 2005b }\end{array}$ \\
\hline & C54G7.4 & IFTA-1 & IFT protein & $n x 61$ & Blacque et al., 2005 \\
\hline & T28F3.6 & IFTA-2 & $\begin{array}{l}\text { IFT protein of the RAB } \\
\text { family; not required for } \\
\text { cilium formation }\end{array}$ & $\operatorname{tm} 1724$ & Schafer et al., 2006 \\
\hline
\end{tabular}




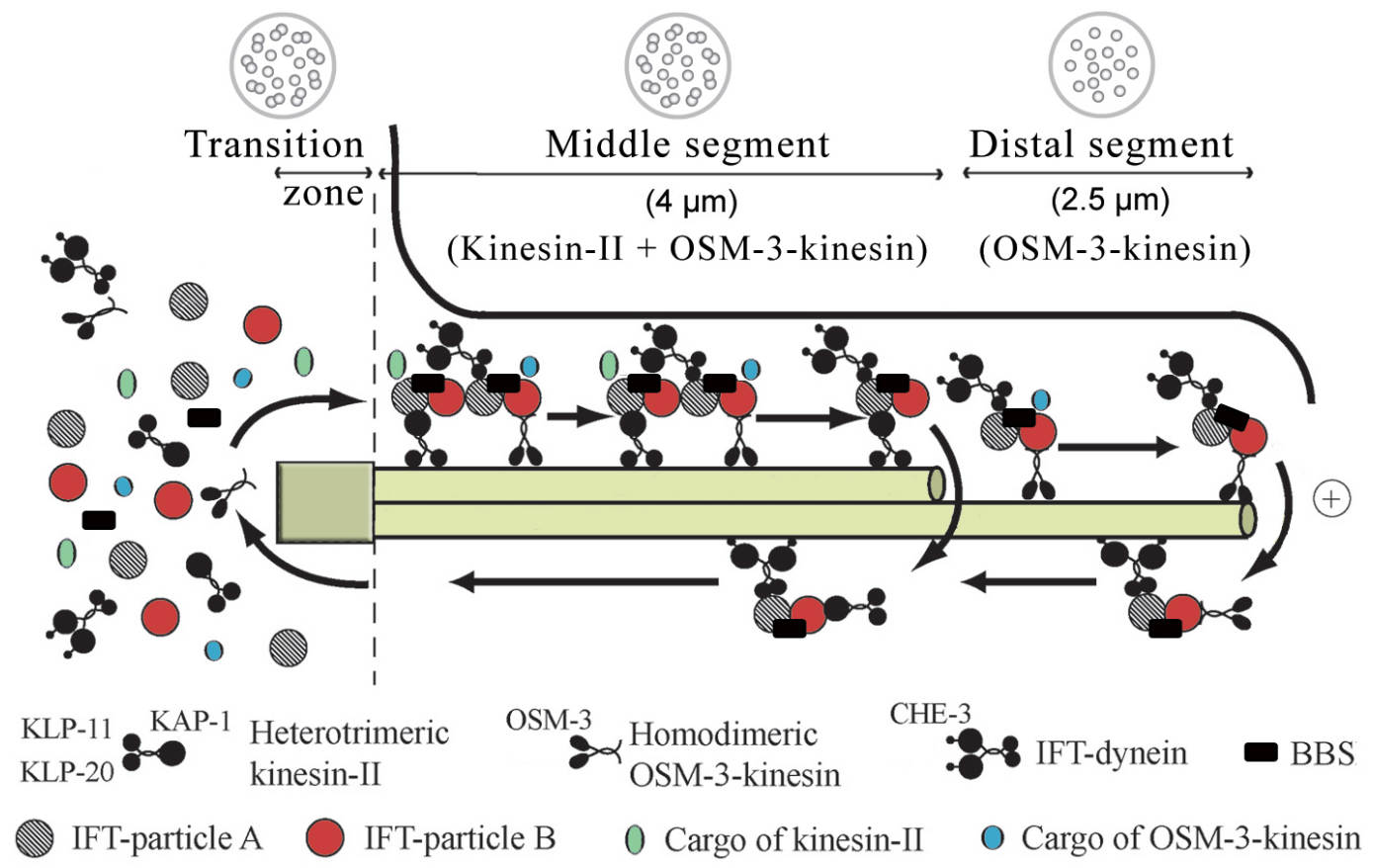

Figure 2. Intraflagellar transport in C. elegans. Intraflagellar transport in C. elegans. Components of the IFT machinery and ciliary cargo assemble at or near the transition zone (basal body). Two kinesins, heterotrimeric kinesin-II and homodimeric OSM-3-kinesin, separately bind IFT particle subcomplexes $\mathrm{A}$ and $\mathrm{B}$, respectively, and transport these together with IFT-dynein and cargo along the middle segment in the anterograde (+) direction. In the distal segment, OSM-3-kinesin alone transports the IFT particles and dynein/cargo. BBS proteins act to stabilize the association between the motors and IFT particle subcomplexes A and B. Components of the IFT machinery and presumably other ciliary molecules are recycled back to the base of the cilium using the IFT-dynein molecular motor. The lengths of the transition zone $(1 \mu \mathrm{m})$, middle segment $(4 \mu \mathrm{m})$ and distal segment $(2.5 \mu \mathrm{m})$ regions are shown (for amphid cilia) along with transverse view schematics of the microtubule arrangements (on top).

The two sequential anterograde IFT-pathways are coordinated by at least two types of regulator proteins. Two C. elegans homologs of human Bardet-Biedl Syndrome (BBS) proteins (BBS-7 and BBS-8) have been shown to stabilize the IFT-particle subcomplexes A and B which are bound to the Kinesin-II and OSM-3 IFT-motors, respectively (Blacque et al., 2004; Ou et al., 2005a; Snow et al., 2004). Abbrogation of BBS protein function results in slightly truncated cilia and chemosensory or lipid accumulation defects (Blacque et al., 2004; Mak et al., 2006). The implications for this observation are of interest given that BBS, which is characterized by a diverse array of ailments, including obesity, cystic kidneys, and retinal degeneration, is one of a growing number of known ciliopathies (Beales, 2005; Blacque and Leroux, 2006). At least eight genes encoding BBS proteins are present in $C$. elegans (Table 2). The second modulator of the sequential IFT pathway, a conserved ciliary protein also first characterized in C. elegans, DYF-1, specifically docks the OSM-3 kinesin onto IFT-particles and simultaneously activates its motor activity; a $d y f-1$ mutant therefore specifically lacks the distal segment singlet microtubules (Ou et al., 2005a).

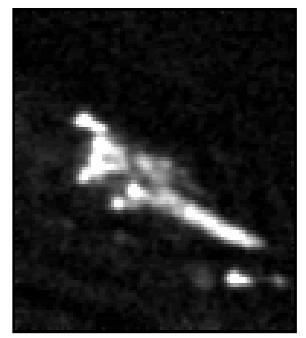

Movie 1. cilia of C. elegans as seen by time-lapse microscopy of GFP-labelled OSM-1.

The ability to analyze strains bearing GFP-tagged IFT proteins by time-lapse microscopy in C. elegans has provided researchers with a powerful means to dissect IFT function and study ciliary mutants (Orozco et al., 1999). Until now, this technique to study cilia function has distinguished $C$. elegans from the other prominent ciliary model 
organism, Chlamydomonas. In addition to providing crucial information about BBS and various IFT-associated proteins such as DYF-1, such in vivo studies are complemented by the fact that in many $C$. elegans ciliary mutants, abnormal IFT causes defects in sensory cilia structures and sensory behavior. For example, osm-3 and che-3 mutants possess defects in the functions of the anterograde IFT-kinesin and retrograde IFT-dynein, respectively, and display structural defects in the sensory cilia and corresponding deficiencies in osmotic avoidance and chemotaxis (Signor et al., 1999a; Wicks et al., 2000). Notably, the first evidence that biochemically-fractionated IFT-particle subunits identified in Chlamydomonas are essential for ciliary assembly was based on the phenotypes of the corresponding $C$. elegans mutants, such as osm-1/IFT172, osm-6/IFT52, osm-5, che-2, che-11 and che-13 and daf-10 (Brazelton et al., 2001; Cole et al., 1998; Qin et al. 2001; Scholey et al., 2004; Table 3). In addition, other components of the IFT machinery present in the Chlamydomonas flagellar proteome but not specifically identified in biochemical fractionations of IFT-particles (Pazour et al., 2005) have first been described in C. elegans, including DYF-2, a protein that may help bridge the IFT subcomplexes A and B (Efimenko et al., 2006), DYF-3, a protein associated with polycystic kidney disease that is likely part of IFT subcomplex B (Ou et al., 2005b), and IFTA-1 (IFT-Associated protein 1), a likely subcomplex A protein (Blacque et al., 2006). Each of these mutants are characterized phenotypically as having cilia structure and chemosensory defects.

Table 3. Cilia-related genes with corresponding genetic map positions and phenotypes

\begin{tabular}{|c|c|c|c|c|c|c|c|c|c|c|}
\hline Name & $\begin{array}{l}\text { Other } \\
\text { name }\end{array}$ & Gene model & $\begin{array}{c}\text { Genetic position } \\
\text { (cM) }\end{array}$ & $\begin{array}{l}\text { Ref. } \\
\text { allele }\end{array}$ & che & daf & $d y f$ & osm & Annotation & Reference \\
\hline che-1 & $\begin{array}{l}\operatorname{tax}-1 \\
\operatorname{tax}-5\end{array}$ & C55B7.12 & $\mathrm{I}: 1.20+/-0.015$ & e1034 & + & I & / & $+/-$ & $\begin{array}{c}\text { C2H2-type } \\
\text { transcription } \\
\text { fact. }\end{array}$ & $\begin{array}{l}\text { Uchida et al., } \\
2003\end{array}$ \\
\hline che-2 & & F38G1.1 & $X:-19.76+/-0.06$ & e1033 & + & + & + & + & IFT-particle B & $\begin{array}{l}\text { Fujiwara et al., } \\
1999\end{array}$ \\
\hline che-3 & $\begin{array}{c}\text { osm-2, } \\
\text { che-8, } \\
\text { avr-1, } \\
\text { caf-2 }\end{array}$ & F18C12.1 & $\mathrm{I}: 2.47+/-0.023$ & e1124 & + & + & + & + & $\begin{array}{l}\text { IFT-dynein } \\
\text { heavy chain }\end{array}$ & $\begin{array}{l}\text { Shakir et al., } \\
1993\end{array}$ \\
\hline che-6 & & & IV:0.00+/-0.000 & e1126 & + & I & / & / & $\begin{array}{c}\text { Abnormal IL2 } \\
\text { basal bodies }\end{array}$ & \\
\hline che-10 & & & $\begin{array}{c}\text { II: }-2.80+/- \\
0.244\end{array}$ & e1809 & + & 1 & + & + & & \\
\hline che-11 & & C27A7.4 & $\mathrm{V}: 3.67+/-0.031$ & e1810 & + & + & + & + & IFT-particle A & Qin et al., 2001 \\
\hline che-12 & & & $\mathrm{V}: 2.28+/-0.105$ & el812 & + & I & $+/-$ & + & $\begin{array}{c}\text { Sheath cell } \\
\text { secretion }\end{array}$ & \\
\hline che-13 & che-9 & F59C6.7 & $\mathrm{I}: 5.05+/-0.029$ & e1805 & + & + & + & + & IFT-particle B & $\begin{array}{l}\text { Haycraft et al., } \\
2003\end{array}$ \\
\hline che-14 & $p t d-1$ & F56H1.1 & $\mathrm{I}: 0.45+/-0.015$ & e1960 & + & l & $+/-$ & I & $\begin{array}{c}\text { Transmembrane } \\
\text { receptor }\end{array}$ & $\begin{array}{l}\text { Michaux et al., } \\
2000\end{array}$ \\
\hline$d a f-6$ & $p t r-7$ & F31F6.5 & $X: 21.50$ & e1377 & + & + & + & + & $\begin{array}{l}\text { Sheath cell } \\
\text { function }\end{array}$ & $\begin{array}{l}\text { Perens and } \\
\text { Shaham, } 2005\end{array}$ \\
\hline daf-10 & osm-4 & & IV:4.05+/- 0.002 & e1387 & + & + & + & + & IFT-particle A & Bell et al., 2006 \\
\hline daf-19 & daf-24 & F33H1.1a & II: $2.11+/-0.012$ & $m 86$ & + & + & + & + & $\begin{array}{c}\text { RFX family } \\
\text { transription fact. }\end{array}$ & $\begin{array}{l}\text { Swoboda et al., } \\
2000\end{array}$ \\
\hline$d y f-1$ & & F54C1.5a & $\mathrm{I}:-0.53+/-0.177$ & $m n 335$ & + & 1 & + & + & $\begin{array}{l}\text { OSM-3-kinesin } \\
\text { activator }\end{array}$ & Ou et al., 2005 \\
\hline$d y f-2$ & & ZK520.1/.3 & III: $21.40+/-0.10$ & $m 160$ & + & I & + & / & IFT protein & $\begin{array}{l}\text { Efimenko et al., } \\
2006\end{array}$ \\
\hline$d y f-3$ & & C04C3.5a & IV:-6.09+/- 1.34 & mn331 & + & I & + & 1 & $\begin{array}{c}\text { IFT protein } \\
\text { associated with } \\
\text { PKD }\end{array}$ & $\begin{array}{l}\text { Murayama et } \\
\text { al., } 2005\end{array}$ \\
\hline
\end{tabular}




\begin{tabular}{|c|c|c|c|c|c|c|c|c|c|c|}
\hline Name & $\begin{array}{l}\text { Other } \\
\text { name }\end{array}$ & Gene model & $\begin{array}{c}\text { Genetic position } \\
\text { (cM) }\end{array}$ & $\begin{array}{c}\text { Ref. } \\
\text { allele }\end{array}$ & che & $d a f$ & $d y f$ & osm & Annotation & Reference \\
\hline$d y f-4$ & & & $\mathrm{~V}: 4.31+/-0.29$ & $m 158$ & + & I & + & I & & \\
\hline$d y f-5$ & & & $\mathrm{I}: 3.62+/-0.036$ & $m n 400$ & + & I & + & I & & \\
\hline$d y f-6$ & & & $\mathrm{X}: 2.19+/-0.050$ & $m 175$ & + & 1 & + & 1 & IFT protein & Bell et al., 2006 \\
\hline$d y f-7$ & & & $\mathrm{X}: 2.18+/-0.046$ & $m 537$ & + & I & + & I & & \\
\hline$d y f-8$ & & C43C 3.3 & $X: 1.44+/-0.005$ & $m 539$ & + & + & + & + & $\begin{array}{l}\text { Transmembrane } \\
\text { receptor } \\
\text { (endoglin } \\
\text { family) }\end{array}$ & $\begin{array}{l}\text { Wicks and } \\
\text { Plasterk, pers. } \\
\text { comm. }\end{array}$ \\
\hline$d y f-9$ & & & $\mathrm{~V}: 24.22+/-0.35$ & $n 1513$ & + & + & + & 1 & & \\
\hline$d y f-10$ & & & $\mathrm{I}: 1.53+/-0.040$ & $e 1383$ & + & 1 & + & 1 & & \\
\hline$d y f-11$ & & & $\mathrm{X}:-18.26+/-0.25$ & ad1303 & + & I & + & I & & \\
\hline$d y f-12$ & & & $\mathrm{X}: 2.18+/-0.074$ & $n r 2344$ & + & + & + & 1 & & \\
\hline$d y f-13$ & & C27H5.7a & II:0.25+/- 0.017 & mn396 & + & + & + & I & $\begin{array}{l}\text { Distal segment } \\
\text { assembly }\end{array}$ & $\begin{array}{l}\text { Blacque et al., } \\
2005\end{array}$ \\
\hline osm-1 & & T27B1.1 & $\begin{array}{c}\mathrm{X}: 24.06+/- \\
0.029\end{array}$ & $p 808$ & + & + & + & + & IFT-particle B & Bell et al., 2006 \\
\hline osm-3 & $\begin{array}{l}\text { caf-1, } \\
\text { klp-2 }\end{array}$ & M02B7.3a & $\begin{array}{c}\text { IV:- } 2.27+/- \\
0.087\end{array}$ & $p 802$ & + & + & + & + & IFT-kinesin & \begin{tabular}{|l} 
Shakir et al., \\
1993
\end{tabular} \\
\hline osm-5 & & Y41G9A.1 & $\mathrm{X}:-12.68+/-0.02$ & $p 813$ & + & + & + & + & IFT-particle B & $\begin{array}{l}\text { Haycraft et al., } \\
2001\end{array}$ \\
\hline osm-6 & & R31.3 & V:3.52+/- 0.025 & $p 811$ & + & + & + & + & IFT-particle B & $\begin{array}{l}\text { Collet et al., } \\
1998\end{array}$ \\
\hline osm-12 & $b b s-7$ & Y75B8A.12 & III:16.09+/-0.297 & $n 1606$ & + & I & + & + & $\begin{array}{l}\text { Distal segment } \\
\text { assembly, IFT } \\
\text { particle stability }\end{array}$ & $\begin{array}{l}\text { Blacque et al., } \\
2004\end{array}$ \\
\hline$b b s-1$ & & Y105E8A.5 & $\mathrm{I}: 24.52+/-0.030$ & okl111 & + & I & + & + & $\begin{array}{c}\text { Distal segment } \\
\text { assembly, IFT } \\
\text { particle stability }\end{array}$ & May et al., 2006 \\
\hline$b b s-8$ & & T25F10.5 & $\mathrm{V}: 0.13+/-0.001$ & $n x 77$ & + & 1 & + & + & $\begin{array}{l}\text { Distal segment } \\
\text { assembly, IFT } \\
\text { particle stability }\end{array}$ & $\begin{array}{l}\text { Blacque et al., } \\
2004\end{array}$ \\
\hline
\end{tabular}

Whereas our understanding of the IFT transport process has matured significantly in the last few years, very little is known about the nature of the proteins that require IFT-mediated transport to reach their ciliary destination. Indeed, only radial spoke proteins had been found to be bona fide IFT cargo proteins in Chlamydomonas (Qin et al., 2004); now, several have surfaced in C. elegans. One class of IFT-cargo are the cilia-localized TRP-type channels OSM-9 and OCR-2, which are implicated in various chemosensory responses (Tobin et al., 2002). Both have been shown to undergo IFT (Qin et al., 2005), marking the first account of a non-axonemal component being visualized to move along a cilium. Interestingly, OSM-9 and OCR-2 depend on each other for their ciliary localization, and ectopic expression of OCR-2 in AWC neurons is sufficient to drive OSM-9 to the cilia in this neuron (Tobin et al., 2002). Another apparent IFT cargo is TUB-1, the C. elegans homolog of the mammalian protein Tubby, which is associated with an obese phenotype (Kleyn et al., 1996; Noben-Trauth et al., 1996). TUB-1 motility has been visualised in both dendrites and cilia, and its function is required for normal lipid homeostasis, life span, and chemotaxis (Mukhopadhyay et al., 2005). Lastly, IFTA-2, a RAB-like protein expressed exclusively in ciliated cells has been shown to undergo IFT, but interestingly, is not required for building an intact cilium. Instead, IFTA-2 may represent a signalling molecule that is required for cilia functions; consistent with this notion, the ifta-2 mutant has an extended lifespan and dauer formation defects that have previously been ascribed to cilia dysfunction (Schafer et al. 2006). 


\section{Transcriptional regulation of cilium morphogenesis}

A defining moment in $C$. elegans cilia research was the publication by Swoboda et al. (2000) which demonstrated that many, if not all genes involved in ciliogenesis are under the transcriptional control of the single RFX-type transcription factor found in the nematode, DAF-19. The promoter element recognized by DAF-19, termed "X box," is normally 14 nucleotides in length and is typically positioned 100 nucleotides upstream from the start codon of the ciliary gene (Swoboda et al., 2000; Haycraft et al., 2001; Ansley et al., 2003; Haycraft et al., 2003; Blacque et al., 2005; Efimenko et al., 2005). When present at this canonical position, an X box drives the specific expression of a gene in most or all 60 ciliated cells. Interestingly, an $\mathrm{X}$ box is found upstream of the daf-19 gene itself, indicating that its activity is self-regulated (Swoboda et al., 2000). Consistent with the role of DAF-19 as a master regulator of ciliogenesis, daf-19 mutants lack all signs of cilia (Perkins et al., 1986; Swoboda et al., 2000). As expected, genes encoding IFT and BBS proteins also possess X boxes. However, unlike daf-19 mutants, disruption of these genes leads to abnormal (truncated) ciliary structures (Perkins et al., 1986; Starich et al., 1995; Blacque et al., 2004; Ou et al., 2005a). For ciliary genes expressed in a subset of ciliated sensory neurons (such as some receptors and possibly other cargo proteins), $\mathrm{X}$ boxes are normally absent but other cell type-specific regulatory elements likely exist.

It is notable that following the discovery by Swoboda et al. (2000) of the critical importance of DAF-19 in regulating cilium formation, RFX transcription factors have been implicated in ciliogenesis in other organisms. In mice, RFX3 is required for the development of embryonic nodal cilia (Bonnafe et al., 2004). Similarly, an RFX protein in Drosophila has been connected to the development of ciliated structures in sensory neurons (Dubruille et al., 2002).

\section{The C. elegans ciliome}

Recent studies in several organisms have contributed to an effort to amalgamate a complete list of ciliary proteins, or 'ciliome.' Comparative genomic studies were performed in Chlamydomonas (Li et al., 2004) and Drosophila (Avidor-Reiss et al., 2004), taking advantage of the fact that subtracting the genomes of ciliated organisms (including C. elegans) from those lacking cilia (e.g., Arabidopsis thaliana) provides considerable enrichment for ciliary genes. Other more direct approaches aimed at identifying ciliary proteins, in the form of proteomic analyses, were performed using Chlamydomonas (Pazour et al., 2005), human airway cells (Ostrowski et al., 2002), Tetrahymena (Smith et al., 2005) and Trypanosoma brucei (Broadhead et al., 2006). Of note, all of the above studies were accomplished using experimental systems or cells that possess motile cilia (with the exception of Drosophila, which also has non-motile cilia). Helping to address this shortfall, C. elegans has been used to assemble a sensory cilium-specific proteome, using both bioinformatic and genomic approaches. Two recent genome-wide studies in C. elegans were used to identify several hundred putative $\mathrm{X}$ box sequences in gene promoters (Blacque et al., 2005; Efimenko et al., 2005), and other studies (Avidor-Reiss et al. 2004; Li et al., 2004) scanned putative ciliary genes for X boxes in C. elegans and Drosophila. Blacque et al. (2005) also combined data from the X box search with comparative analyses of SAGE (transcriptome) libraries (ciliated neuron, pan-neuronal, gut and muscle) to enrich for genes preferentially expressed in ciliated neurons. Similarly, Kunimoto et al. (2005) developed a list of ciliated sensory neuron-expressed genes by performing a targeted pulldown of mRNA polyA tails. The ability to isolate individual cell types from $C$. elegans is also proving to be a powerful means to uncover the specific transcriptomes and functions of ciliated cells. Recently, Colosimo et al. (2004) isolated AWB olfactory and AFD thermosensory neurons, and used microarrays to obtain their expression profiles.

Taken together, these complementary studies have resulted in the compilation of comprehensive lists of known and candidate ciliary proteins, as outlined in several review articles (Inglis et al., 2006; Gherman et al., 2006; Fliegauf and Omran, 2006). In addition, two websites provide useful resources for ciliary researchers, including the ability to search the different ciliary datasets (http://www.ciliome.com and http://www.ciliaproteome.org). Following the identification of putative ciliary genes, it is straightforward to test in C. elegans whether these genes are likely to be required for cilia function. Specifically, these genes, as tested by expression using a promoter fused to GFP, should be at least expressed in some, or all ciliated sensory neurons. For example, many novel putative ciliary genes were found to be expressed specifically in ciliated neurons in Blacque et al. (2005) and Efimenko et al. (2005). Further analysis of putative ciliary genes may also include making translational fusions to GFP to determine if the protein is associated with ciliary structures, including transition zones and the ciliary axoneme (e.g., see Blacque et al., 2005). Lastly, testing of the mutant for ciliary phenotypes such as Che, Osm, Dyf and Daf, or changes in lifespan, as described below, can provide strong evidence that a particular gene plays an important role in the differentiation of ciliated cell(s), in the formation of cilia, and/or in the physiological function(s) of cilia. 


\section{Understanding $C$. elegans ciliary functions through ciliary mutant analysis}

The availability of large numbers of existing ciliary mutants is in large part the result of the vision of molecular biologist Sydney Brenner, who foresaw the value of this organism for studying the genetics of development and nervous system function. To this end, he and many of his scientific progeny sought nervous system mutants that displayed behavioral and structural defects, a number of which affect cilia and/or ciliated cell function or differentiation. Table 3 shows a selection of genes known to affect cilia formation and function, along with map positions and phenotypes.

\subsection{Dye filling (Dyf) phenotype}

The simplest method presently used to assay the structural integrity of sensory cilia is to test the ability of worms to take up a fluorescent dye. One type of dye (DiI) preferentially fills amphid head neuronsand phasmid tail neurons, presumably via their exposed ciliated endings, although the exact mechanism of dye uptake is unclear (Perkins et al., 1986; Starich et al., 1995). The dye enters 6 amphid (ASI, ADL, ASK, AWB, ASH and ASJ) and the two phasmid (PHA and PHB) neurons (Herman, 1984). Similar staining patterns are seen with DiO or FITC (Hedgecock et al., 1985). Among others, mutants with abrogated BBS or IFT proteins exhibit an abnormal dye filling (Dyf) phenotype (Table 3). Although this phenotype has been tightly associated with abnormal cilia, alterations to the ciliated neuron sheath and socket cells may also confer a Dyf phenotype if the cilia in question lose access to the environment-as seen for example in daf-6 mutants (Perens and Shaham, 2005). It should be noted, however, that the lack of a Dyf mutant phenotype does not always imply proper cilium structure or function, e.g., the non-Dyf mutant ifta-2 exhibits at least two ciliary mutant phenotypes, increased longevity and defective dauer formation (Schafer et al. 2006).

\subsection{Chemosensory (Che) and osmosensory (Osm) phenotypes}

In addition to the dye-filling experiments, a number of behavioral assays have been employed to identify mutant worms with defective cilia. The osmotic avoidance abnormal (Osm) phenotype is often associated with cilia defects in C. elegans (Perkins et al., 1986; Table 3). Unlike wild-type worms, osm mutants fail to avoid regions with high osmotic strength, such as $4 \mathrm{M} \mathrm{NaCl}$ or $8 \mathrm{M}$ glycerol (Culotti and Russell, 1978). Similarly, chemotaxis to both volatile and non-volatile compounds is dependent on the cilia present at the tips of a number of sensory neurons; defects in this sensory process represents an abnormal che motaxis (Che) phenotype (Ward, 1973; Bargmann et al., 1993). Numerous osm and che mutants have been identified (Culotti and Russell, 1978; Ward, 1973). Interestingly, virtually all such mutants that possess abrogated cilia structures display most, if not all, of the aforementioned mutant phenotypes, indicating a vital role for cilia in the regulation of responses to external stimuli (Lewis and Hodgkin, 1977), and many of the $\mathrm{osm}$ and che mutants isolated have been found to encode proteins essential for cilia structure/function (Tables 2 and 3; Perkins et al., 1986). A thorough treatment of chemosensation is presented in the Wormbook chapter by Cornelia Bargmann (see Chemosensation in C. elegans).

\subsection{Mechanosensory (Mec) phenotypes}

Despite the observation that some touch-response cells are non-ciliated (Chalfie and Sulston, 1981), two mechanosensory mutants, mec-1 and mec-8, also display a Dyf phenotype (Perkins et al., 1986). Indeed, the ASH, ADE, PDE, CEP, FLP, IL1, OLQ, and OLL ciliated neurons have been connected to mechanosensation (Table 1; Sawin et al., 2000; Hart et al. 1995; Kaplan and Horvitz, 1993), suggesting that cilia may possess a mechanosensory role, similar to that of the kidney tubule cilia that sense fluid flow in mammals (Nauli and Zhou, 2004). Furthermore, the ciliary mutants che-2, che-3, che-13, osm-6, che-12 and osm-3 all show significantly reduced abilities to respond to a touch on the nose of the animal (Kaplan and Horvitz, 1993). For a complete review of mechanosensation in C. elegans, see Mechanosensation. Interestingly, the amphid ASH neuron has been connected to both noxious chemical avoidance (Bargmann et al., 1990) and nose-touch response, raising intriguing parallels between this neuron and the nociceptive neurons of vertebrate cells (Kaplan and Horvitz, 1993).

\subsection{Male mating phenotypes}

Another interesting role played by cilia in C. elegans involves male mating behavior. Male worms with defective cilia function are unable to sense the chemical cue(s) underlying mate-finding (Lipton et al., 2004). In addition to being defective in locating hermaphrodites, males with abrogated cilium function also show compromised abilities to locate the vulva and ejaculate (Barr and Sternberg, 1999; Qin et al., 2001). For a detailed description of male mating behavior, see Male mating behavior. 


\subsection{Dauer and lifespan phenotypes}

Worms completely lacking sensory cilia appear to constitutively enter the alternate life stage known as dauer (i.e., Daf-constitutive or Daf-c), offering an intriguing connection between cilia, lifespan and stress resistance. The basis for this connection is the observation that abrogation of DAF-19 function, which leads to a complete loss of cilia, results in significantly longer-lived worms (in the dauer stage). It should be noted, however, that since DAF-19 is a transcription factor, the Daf-c phenotype observed might be due to effects on downstream targets unrelated to ciliogenesis, although, only cilia-associated proteins have been shown to be regulated by DAF-19. Perhaps more convincingly, initial analysis of Daf mutants indicated that dauer-forming or exit responses were mediated by environmental stimuli (Riddle et al., 1981). Interestingly, cilium structure mutants such as daf-6 and daf-10 frequently show an inability to enter dauer (Daf-defective or Daf-d; Perens and Shaham, 2005; Bell et al., 2006). Furthermore, there are other potentially fascinating connections between cilia and longevity in C. elegans that do not appear to specifically involve the dauer pathway. Laser ablation of certain ciliated neurons results in increased lifespan, and a number of ciliary mutants live longer, perhaps due to their altered sensory perception (Apfeld and Kenyon, 1999). Further connections between sensory cilia and longevity have been discovered through analysis of oxidative stress mutants, which showed that mutants resistant to methyl viologen (also known as paraquat) were frequently found to be defective in cilia. MEV-4 (methyl viologen resistant 4), for example, was found to be CHE-11, an integral component of IFT subcomplex A (Fujii et al., 2004).

\subsection{Thermosensory phenotypes}

Although a direct connection between cilia and thermosensation of physiological temperatures has yet to be established (Perkins et al., 1986), the sole thermosensory neuron in C. elegans, AFD, is indeed ciliated, raising the possibility that cilia, perhaps in addition to its microvilli (Ward et al., 1975; Ware et al., 1975; Perkins et al., 1986), may be required for proper function of this neuron. One study has revealed that several ciliary mutants display abnormal responses to noxious temperatures, although the sensory neurons implicated in the response remain unidentified (Wittenburg and Baumeister, 1999).

\subsection{Lipid accumulation phenotypes}

Recently, connections have been made in $C$. elegans between sensory cilia and lipid accumulation. The $C$. elegans mutant tub-1, in which the worm homolog of the mouse protein Tubby is disrupted, was discovered by Ashrafi et al. (2003) to have a two-fold increase in fat content via Nile Red analysis (which assesses lipid content) compared to wild-type. TUB-1 has subsequently been shown to localize to the axons, dendrites, and cilia of the amphid, phasmid, AQR and PQR neurons (Mak et al. 2006). Chemotaxis in tub-1 mutants is impaired, although tub-1 mutants show no abrogation of ciliary structure based on a normal DiI-filling phenotype (Mak et al., 2006; Mukhopadhyay et al., 2005). A screen for mutants which enhanced the Nile Red accumulation phenotype of $t u b-1$ identified that a mutation in a 3-ketoacyl-coA thiolase, known as kat-1. Interestingly, a screen for mutants that enhanced the kat-1 mutant Nile Red-accumulation phenotype resulted in the identification of $b b s-1$, a conserved gene implicated in the obesity-associated Bardet-Biedl Syndrome (Mak et al. 2006). Although TUB-1 has been strongly connected to intestinal/muscle KAT-1, additional research has indicated that the protein is positioned between DAF-2 and DAF-16 in the dauer signaling pathway (Mukhopadhyay et al., 2005).

\section{C. elegans as a model system to study ciliopathies}

Defects in the highly conserved components of cilia and the IFT machinery are now understood to contribute to several human ciliary disorders. These include Primary Ciliary Dyskinesia (PCD) which arises from defects in motile cilia, as well as several related to sensory cilia dysfunction, such as polycystic kidney disease (PKD), Bardet-Biedl syndrome (BBS), Meckel syndrome (MKS) and nephronophthisis. C. elegans has emerged as an important model system for studying the molecular bases of some of these sensory-related ciliopathies, as illustrated below.

Although $C$. elegans does not develop a kidney, several disease genes associated with defects in renal cilia function have homologs in $C$. elegans. Mutations in worm homologs of the autosomal dominant polycystic kidney-disease loci PKD1 and PKD2, lov-1 and $p k d-2$, were shown to produce defects in male mating behavior and provided the first link between ciliary dysfunction and PKD (Barr and Sternberg, 1999). This breakthrough finding has been confirmed in a number of model systems, including zebrafish, where most mutant animals displaying cystic kidneys possess disruptions in genes associated with cilia function (Sun et al., 2004). Additionally, it has been shown that $C$. elegans LOV-1 is required for the proper targeting of PKD-2 to the cilium of in the male-specific 
neurons CEM, as well as 8 pairs of ray neurons (Bae et al., 2006). A further finding is that in a daf-10 mutant background (which disrupts IFT subcomplex A), the ciliary localization of PKD-2 is significantly altered, resulting in accumulations in the transition zone as well as the dendrite (Bae et al., 2006).

Worm homologs of the proteins NPHP-1 and NPHP-4, which are implicated in the kidney disorder nephronophthisis, localize specifically to the transition zones of sensory cilia, where they appear to be involved in IFT-independent sensory signal transduction (Jauregui and Barr, 2005; Winkelbauer et al., 2005; Wolf et al., 2005).

Studies in C. elegans also provided the first evidence that BBS proteins-which are implicated in a wide array of ailments, including obesity, retinal degeneration and cystic kidney disease-are essential ciliary proteins that contribute to intraflagellar transport by stabilizing the association between kinesin motors and intraflagellar subcomplex assemblies (Ansley et al., 2003, Blacque et al., 2004; Ou et al., 2005a). Remarkably, all but 3 of the 11 known human $B B S$ genes possess $C$. elegans orthologues, making the nematode an excellent model system to study this multigenic and pleiotropic disorder.

Finally, two genes (MKS1 and MKS3) associated with Meckel-Gruber syndrome (MKS) (Kyttala et al., 2006; Smith et al., 2006), the most common form of syndromic neural tube defects, were recently cloned, and both of their C. elegans homologs ( $x b x$-7/R148.1 and F35D2.4, respectively) were found to be specifically expressed in ciliated sensory neurons (Efimenko et al., 2005; Blacque et al., 2005). This observation strongly suggests that MKS is a ciliopathy. It will therefore be of interest to analyze the subcellular localization and functions of the $C$. elegans MKS proteins in order to provide important clues as to the cause of the disorder.

\section{Concluding remarks}

Given the diverse array of in vivo tools available for studying intraflagellar transport, ciliary integrity, and cilia mutants, $C$. elegans sits in a unique position to facilitate our understanding of cilium biogenesis and fundamental cilia functions as they relate to a complex multicellular organism. For instance, although much insight has been gained to date on the molecular makeup of the intraflagellar transport machinery, additional proteins that participate in and regulate the IFT process will likely be found, and the functions of some of the known players will likely be clarified using $C$. elegans as a model system. There are a large number of different modalities under the control of cilia function, but others are bound to be discovered, and importantly, parallels with mammalian systems-insofar as lipid homeostasis and longevity is concerned, for example-will ultimately become apparent. The nematode is also well poised to help shed additional light on the molecular etiology of various ciliopathies. For example, identification of additional Dyf mutants and characterization of their phenotypes may help uncover new genes related to Bardet-Biedl syndrome or other ciliopathies. In brief, C. elegans researchers should be able to make excellent progress in the study of this fascinating cellular organelle that is drawing an increasing amount of attention due to its breadth of physiological functions and association with a wide range of ailments.

\section{Acknowledgements}

We would like to acknowledge the members of the $C$. elegans research community for all of their contributions to the field of ciliary research in the worm. This research is supported by grants from the Canadian Institutes of Health Research (CIHR; CBM134736), the March of Dimes (M.R.L.), and NIH grant GM 50718 (J.M.S). M.R.L. is supported by scholar awards from CIHR and the Michael Smith Foundation for Health Research (MSFHR).

\section{References}

Albert, P.S., Brown, S.J., and Riddle, D.L. (1981). Sensory control of dauer larva formation in Caenorhabditis elegans. J. Comp. Neurol. 198, 435-451. Abstract Article

Ansley, S.J., Badano, J.L., Blacque, O.E., Hill, J., Hoskins, B.E., Leitch, C.C., Kim, J.C., Ross, A.J., Eichers, E.R., Teslovich, T.M., Mah, A.K., Johnsen, R.C., Cavender, J.C., Lewis, R.A., Leroux, M.R., Beales, P.L., and Katsanis, N. (2003). Basal body dysfunction is a likely cause of pleiotropic Bardet-Biedl syndrome. Nature 425, 628-633. Abstract Article

Apfeld, J., and Kenyon, C. (1999). Regulation of lifespan by sensory perception in Caenorhabditis elegans. Nature 402, 804-809. Abstract Article 
Ashrafi, K., Chang, F.Y., Watts, J.L., Fraser, A.G., Kamath, R.S., Ahringer, J., and Ruvkun, G. (2003). Genome-wide RNAi analysis of Caenorhabditis elegans fat regulatory genes. Nature 421, 268-272. Abstract Article

Avidor-Reiss, T., Maer, A.M., Koundakjian, A., Polyanovsky, T., Keil, S., and Zuker, C.S. (2004). Decoding cilia function: defining specialized genes required for compartmentalized cilia biogenesis. Cell 117, 527-529. Abstract Article

Bae, Y.K., Qin, H., Knobel, K.M., Hu, J., Rosenbaum, J.L., and Barr, M.M. (2006). General and cell-type specific mechanisms target TRPP2/PKD-2 to cilia. Development 133, 3859-3870. Abstract Article

Bargmann, C.I., Hartweig, E., and Horvitz, H.R. (1993). Odorant-selective genes and neurons mediate olfaction in C. elegans. Cell 74, 515-527. Abstract Article

Bargmann, C.I., Thomas, J.H., and Horvitz, H.R. (1990). Chemosensory cell function in the behavior and development of Caenorhabditis elegans. Cold Spring Harb. Symp. Quant. Biol. 55, 529-538. Abstract

Barr, M.M., and Sternberg, P.W. (1999). A polycystic kidney-disease gene homologue required for male mating behaviour in C. elegans. Nature 401, 386-389. Abstract

Beales P.L. (2005). Lifting the lid on Pandora's box: the Bardet-Biedl syndrome. Curr. Opin. Genet. Dev. 15, 315-323. Abstract Article

Bell, L.R., Stone, S., Yochem, J., Shaw, J.E., and Herman, R.K. (2006). The molecular identities of the Caenorhabditis elegans intraflagellar transport genes dyf-6, daf-10, and osm-1. Genetics 173, 1275-1286. Abstract Article

Blacque, O.E., and Leroux, M.R. (2006). Bardet-Biedl syndrome: an emerging pathomechanism of intracellular transport. Cell Mol. Life Sci. 63, 2145-2161. Abstract Article

Blacque, O.E., Li, C., Inglis, P.N., Esmail, M.A., Ou, G., Mah, A.K., Baillie, D.L., Scholey, J.M., and Leroux, M.R. (2006). The WD Repeat-containing Protein, IFTA-1, Is Required for Retrograde Intraflagellar Transport. Mol. Biol. Cell Oct 4; [Epub ahead of print]. Abstract

Blacque, O.E., Perens, E.A., Boroevich, K.A., Inglis, P.N., Li, C., Warner, A., Khattra, J., Holt, R.A., Ou, G., Mah, A.K., McKay, S.J., Huang, P., Swoboda, P., Jones, S.J., Marra, M.A., Baillie, D.L., Moerman, D.G., Shaham, S., and Leroux, M.R. (2005). Functional genomics of the cilium, a sensory organelle. Curr. Biol. 15, 935-941. Abstract Article

Blacque, O.E., Reardon, M.J., Li, C., McCarthy, J., Mahjoub, M.R., Ansley, S.J., Badano, J.L., Mah, A.K., Beales, P.L., Davidson, W.S., Johnsen, R.C., Audeh, M., Plasterk, R.H., Baillie, D.L., Katsanis, N., Quarmby, L.M., Wicks, S.R., and Leroux, M.R. (2004). Loss of $C$. elegans BBS-7 and BBS-8 protein function results in cilia defects and compromised intraflagellar transport. Genes Dev. 18, 1630-1642. Abstract Article

Bonnafe, E., Touka, M., AitLouis, A., Baas, D., Barras, E., Ucla, C., Moreau, A., Flamant, F., Dubruille, R., Couble, P, Collignon, J., Durand, B., and Reith, W. (2004). The transcription factor RFX3 directs nodal cilium development and left-right asymmetry specification. Mol. Cell Biol. 24, 4417-4427. Abstract Article

Brazelton, W.J., Amundsen, C.D., Silflow, C.D., and Lefebvre, P.A. (2001). The bld1 mutation identifies the Chlamydomonas osm-6 homolog as a gene required for flagellar assembly. Curr. Biol. 11, 1591-1594. Abstract Article

Broadhead, R., Dawe, H.R., Farr, H., Griffiths, S., Hart, S.R., Portman, N., Shaw, M.K., Ginger, M.L., Gaskell, S.J., McKean, P.G., and Gull, K. (2006). Flagellar motility is required for the viability of the bloodstream trypanosome. Nature 440, 224-227. Abstract Article

Chalfie, M., and Sulston, J.E. (1981). Developmental genetics of the mechanosensory neurons of Caenorhabditis elegans. Dev. Biol. 82, 358-370. Abstract Article 
Cheung, B.H., Cohen, M., Rogers, C., Albayram, O., de Bono, M. (2005). Experience-dependent modulations of $C$. elegans behavior by ambient oxygen. Curr. Biol. 15, 905-917. Abstract Article

Cheung, B.H., Arellano-Carbajal, F., Rybicki, I., and de Bono, M. (2004). Soluble guanylate cyclases act in neurons exposed to the body fluid to promote $C$. elegans aggregation behavior. Curr. Biol. 14, 1105-1111. Abstract Article

Colbert, H.A., Smith, T.L., and Bargmann, C.I. (1997). OSM-9, a novel protein with structural similarity to channels, is required for olfaction, mechanosensation, and olfactory adaptation in Caenorhabditis elegans. J. Neurosci. 17, 8259-8269. Abstract

Cole, D.G., Diener, D.R., Himelblau, A.L., Beech, P.L., Fuster, J.C., and Rosenbaum, J.L. (1998). Chlamydomonas kinesin-II-dependent intraflagellar transport (IFT): IFT particles contain proteins required for ciliary assembly in Caenorhabditis elegans sensory neurons. J. Cell Biol. 141, 993-1008. Abstract Article

Collet, J., Spike, C.A., Lundquist, E.A., Shaw, J.E., and Herman, R.K. (1998). Analysis of osm-6, a gene that affects sensory cilium structure and sensory neuron function in Caenorhabditis elegans. Genetics 148, 187-200. Abstract

Colosimo, M.E., Brown, A., Mukhopadhyay, S., Gabel, C., Lanjuin, A.E., Samuel, A.D., amd Sengupta, P. (2004). Identification of thermosensory and olfactory neuron-specific genes via expression profiling of single neuron types. Curr. Biol. 14, 2245-2251. Abstract Article

Culotti, J.G., and Russell, R.L. (1978). Osmotic avoidance defective mutants of the nematode Caenorhabditis elegans. Genetics 90, 243-256. Abstract

Dubruille, R., Laurencon, A., Vandaele, C., Shishido, E., Coulon-Bublex, M., Swoboda, P., Couble, P., Kernan, M., and Durand, B. (2002). Drosophila regulatory factor X is necessary for ciliated sensory neuron differentiation. Development 129, 5487-5498. Abstract Article

Dusenbery, D.B. (1974). Analysis of chemotaxis in the nematode Caenorhabditis elegans by countercurrent separation. J. Exp. Zool. 188, 41-47. Abstract Article

Dusenbery, D.B., Sheridan, R.E., Russell, R.L. (1975). Chemotaxis-defective mutants of the nematode Caenorhabditis elegans. Genetics 80, 297-309. Abstract

Efimenko, E., Bubb, K., Mak, H.Y., Holzman, T., Leroux, M.R., Ruvkun, G., Thomas, J.H., and Swoboda P. (2005). Analysis of $x b x$ genes in C. elegans. Development 132, 1923-1934. Abstract Article

Efimenko, E., Blacque, O.E., Ou, G., Haycraft, C.J., Yoder, B.K., Scholey, J.M., Leroux, M.R., and Swoboda, P. (2006). Caenorhabditis elegans DYF-2, an ortholog of human WDR19, is a component of the IFT Machinery in sensory cilia. Mol. Biol. Cell 17, 4801-4811. Abstract Article

Evans JE, Snow JJ, Gunnarson AL, Ou G, Stahlberg H, McDonald KL, and Scholey JM. (2006). Functional modulation of IFT kinesins extends the sensory repertoire of ciliated neurons in Caenorhabditis elegans. J. Cell Biol. 172, 663-669. Abstract Article

Fan, Y., Esmail, M.A., Ansley, S.J., Blacque, O.E., Boroevich, K., Ross, A.J., Moore, S.J., Badano, J.L., May-Simera, H., Compton, D.S., Green, J.S., Lewis, R.A., Van Haelst, M.M., Parfrey, P.S., Baillie, D.L., Beales, P.L., Katsanis, N., Davidson, W.S., and Leroux, M.R. (2004). Mutants in a member of the Ras superfamily of small GTP-binding proteins causes Bardet-Biedl Syndrome. Nat. Genet. 36, 989-993. Abstract Article

Fliegauf, M., and Omran, H. (2006). Novel tools to unravel molecular mechanisms in cilia-related disorders. Trends Genet. 22, 241-245. Abstract Article

Fujii, M., Matsumoto, Y., Tanaka, N., Miki, K., Suzuki, T., Ishii, N., and Ayusawa, D. (2004). Mutations in chemosensory cilia cause resistance to paraquat in nematode Caenorhabditis elegans. J. Biol. Chem. 279, 20277-20282. Abstract Article

Fujiwara, M., Ishihara, T., and Katsura, I. (1999). A novel WD40 protein, CHE-2, acts cell-autonomously in the formation of C. elegans sensory cilia. Development 126, 4839-4848. Abstract 
Gherman, A., Davis, E.E., and Katsanis, N. (2006). The ciliary proteome database: an integrated community resource for the genetic and functional dissection of cilia. Nat. Genet. 38, 961-962. Abstract Article

Hall, D.H., and Russell, R.L. (1991). The posterior nervous system of the nematode Caenorhabditis elegans: serial reconstruction of identified neurons and complete pattern of synaptic interactions. J. Neurosci. 11, 1-22. Abstract

Hart, A.C., Sims, S., and Kaplan, J.M. (1995). Synaptic code for sensory modalities revealed by C. elegans GLR-1 glutamate receptor. Nature 378, 82-85. Abstract Article

Haycraft, C.J., Swoboda, P., Taulman, P.D., Thomas, J.H., and Yoder, B.K. (2001). The C. elegans homolog of the murine cystic kidney disease gene Tg737 functions in a ciliogenic pathway and is disrupted in $0 s m-5$ mutant worms. Development 128, 1493-1505. Abstract

Haycraft, C.J., Schafer, J.C., Zhang, Q., Taulman, P.D., and Yoder, B.K. (2003). Identification of CHE-13, a novel intraflagellar transport protein required for cilia formation. Exp. Cell Res. 284, 251-263. Abstract Article

Hedgecock, E.M., Culotti, J.G., Thomson, J.N., and Perkins, L.A. (1985). Axonal guidance mutants of Caenorhabditis elegans identified by filling sensory neurons with fluorescein dyes. Dev. Biol. 111, 158-170. Abstract Article

Herman, R.K. (1984). Analysis of genetic mosaics of the nematode Caenorhabditis elegans. Genetics 108, $165-180$. Abstract

Hidaka, K., Ashizawa, N., Endoh, H., Watanabe, M., and Fukumoto, S. (1995). Fine structure of the cilia in the pancreatic duct of WBN/Kob rat. Int. J. Pancreatol. 18, 207-213. Abstract

Hilliard, M.A., Bergamasco, C., Arbucci, S., Plasterk, R.H., and Bazzicalupo, P. (2004). Worms taste bitter: ASH neurons, QUI-1, GPA-3 and ODR-3 mediate quinine avoidance in Caenorhabditis elegans. EMBO J. 23, 1101-1111. Abstract Article

Hilliard, M.A., Bargmann, C.I., Bazzicalupo, P. (2002). C. elegans responds to chemical repellents by integrating sensory inputs from the head and the tail. Curr. Biol. 12, 730-734. Abstract Article

Inglis, P.N., Boroevich, K.A., and Leroux, M.R. (2006). Piecing together a ciliome. Trends Genet. 22, $491-500$. Abstract Article

Jauregui, A.R., and Barr, M.M. (2005). Functional characterization of the C. elegans nephrocystins NPHP-1 and NPHP-4 and their role in cilia and male sensory behaviors. Exp. Cell Res. 305, 333-342. Abstract Article

Kahn-Kirby, A.H., and Bargmann, C.I. (2006). TRP channels in C. elegans. Ann. Rev. Physiol. 68, 719-736. Abstract Article

Kaplan, J.M., and Horvitz, H.R. (1993). A dual mechanosensory and chemosensory neuron in Caenorhabditis elegans. Proc. Natl. Acad. Sci. U.S.A. 90, 2227-2231. Abstract Article

Kleyn, P.W., Fan, W., Kovats, S.G., Lee, J.J., Pulido, J.C., Wu, Y., Berkemeier, L.R., Misumi, D.J., Holmgren, L., Charlat, O., Woolf, E.A., Tayber, O., Brody, T., Shu, P., Hawkins, F., Kennedy, B., Baldini, L., Ebeling, C., Alperin, G.D., Deeds, J., Lakey, N.D., Culpepper, J., Chen, H., Glucksmann-Kuis, M.A., Carlson, G.A., Duyk, G.M., Moore, K.J. (1996). Identification and characterization of the mouse obesity gene tubby: a member of a novel gene family. Cell 85, 281-290. Abstract Article

Kunimoto, H., Uesugi, H., Kohara, Y., and Iino, Y. (2005). Identification of ciliated sensory neuron-expressed genes in Caenorhabditis elegans using targeted pull-down of poly(A) tails. Genome Biol. 6, R17. Abstract Article

Kyttala, M., Tallila, J., Salonen, R., Kopra, O., Kohlschmidt, N., Paavola-Sakki, P., Peltonen, L., and Kestila, M. (2006). MKS1, encoding a component of the flagellar apparatus basal body proteome, is mutated in Meckel syndrome. Nat. Genet. 38, 155-157. Abstract Article 
Lewis, J.A., and Hodgkin, J.A. (1977). Specific neuroanatomical changes in chemosensory mutants of the nematode Caenorhabditis elegans. J. Comp. Neurol. 172, 489-510. Abstract Article

Li, J.B., Gerdes, J.M., Haycraft, C.J., Fan, Y., Teslovich, T.M., May-Simera, H., Li, H., Blacque, O.E., Li, L., Leitch, C.C., Lewis, R.A., Green, J.S., Parfrey, P.S., Leroux, M.R., Davidson, W.S., Beales, P.L., Guay-Woodford, L.M., Yoder, B.K., Stormo, G.D., Katsanis, N., and Dutcher, S.K. (2004). Comparative genomics identifies a flagellar and basal body proteome that includes the BBS5 human disease gene. Cell 14, 541-552. Abstract Article

Lipton, J. (2005). Mating worms and the cystic kidney: Caenorhabditis elegans as a model for renal disease. Pediatr. Nephrol. 20, 1531-1536. Abstract Article

Mak, H.Y., Nelson, L.S., Basson, M., Johnson, C.D., and Ruvkun, G. (2006). Polygenic control of Caenorhabditis elegans fat storage. Nat. Genet. 38, 363-368. Abstract Article

Mesland, D.A.M., Hoffman, J.L., Caligor, E., and Goodenough, U.W. (1980). Flagellar tip activation stimulated by membrane adhesions in Chlamydomonas gametes. J. Cell Biol. 84, 599-617. Abstract Article

Michaux, G., Gansmuller, A., Hindelang, C., and Labouesse, M. (2000). CHE-14, a protein with a sterol-sensing domain, is required for apical sorting in C. elegans ectodermal epithelial cells. Curr. Biol. 10, 1098-1107. Abstract Article

Mukhopadhyay, A., Deplancke, B., Walhout, A.J., and Tissenbaum, H.A. (2005). C. elegans tubby regulates life span and fat storage by two independent mechanisms. Cell Metab. 2, 35-42. Abstract Article

Murayama, T., Toh, Y., Ohshima, Y., and Koga, M. (2005). The $d y f-3$ gene encodes a novel protein required for sensory cilium formation in Caenorhabditis elegans. J. Mol. Biol. 346, 677-687. Abstract Article

Nauli, S.M., and Zhou, J. (2004). Polycystins and mechanosensation in renal and nodal cilia. Bioessays 26, 844-856. Abstract Article

Nelson, G., Roberts, T., and Ward, S. (1982). Caenorhabditis elegans spermatozoan locomotion: amoeboid movement with almost no actin. J. Cell Biol. 92, 121-131. Abstract Article

Noben-Trauth, K., Naggert, J.K., North, M.A., and Nishina, P.M. (1996). A candidate gene for the mouse mutation tubby. Nature 380, 534-538. Abstract Article

Orozco, J.T., Wedaman, K.P., Signor, D., Brown, H., Rose, L., and Scholey, J.M. (1999). Movement of motor and cargo along cilia. Nature 398, 674. Abstract Article

Ostrowski, L.E., Blackburn, K., Radde, K.M., Moyer, M.B., Schlatzer, D.M., Moseley, A., and Boucher, R.C. (2002). A proteomic analysis of human cilia: identification of novel components. Mol. Cell Proteomics 1, 451-465. Abstract Article

Ou, G., Blacque, O.E., Snow, J.J., Leroux, M.R., and Scholey, J.M. (2005a). Functional coordination of intraflagellar transport motors. Nature 436, 583-587. Abstract Article

Ou, G., Qin, H., Rosenbaum, J.L., and Scholey, J.M. (2005b). The PKD protein qilin undergoes intraflagellar transport. Curr. Biol. 15, R410-R411. Abstract Article

Pazour, G.J., Agrin, N., Leszyk, J., and Witman, G.B. (2005). Proteomic analysis of a eukaryotic cilium. J. Cell Biol. 170, 103-113. Abstract Article

Peden, E., and Barr, M. (2005). The KLP-6 kinesin is required for male mating behaviors and polycystin localization in Caenorhabditis elegans. Curr. Biol. 15, 394-404. Abstract Article

Perens, E.A., and Shaham, S. (2005). C. elegans daf-6 encodes a patched-related protein required for lumen formation. Dev. Cell 8, 893-906. Abstract Article 
Perkins, L.A., Hedgecock, E.M., Thomson, J.N., and Culotti, J.G. (1986). Mutant sensory cilia in the nematode Caenorhabditis elegans. Dev. Biol. 117, 456-487. Abstract Article

Qin, H., Rosenbaum, J.L., and Barr, M.M. (2001). An autosomal recessive polycystic kidney disease gene homolog is involved in intraflagellar transport in C. elegans ciliated sensory neurons. Curr. Biol. 11, 457-461. Abstract Article

Qin H, Diener DR, Geimer S, Cole DG, and Rosenbaum J.L. (2004). Intraflagellar transport (IFT) cargo: IFT transports flagellar precursors to the tip and turnover products to the cell body. J. Cell Biol. 164, 255-66. Abstract Article

Qin, H., Burnette, D.T., Bae, Y.K., Forscher, P., Barr, M.M., and Rosenbaum, J.L. (2005). Intraflagellar transport is required for the vectorial movement of TRPV channels in the ciliary membrane. Curr. Biol. 15, 1695-1699. Abstract Article

Reese, T.S. (1965). Olfactory cilia in the frog. J. Cell Biol. 25, 209-230. Article

Riddle, D.L., Swanson, M.M., and Albert, P.S. (1981). Interacting genes in nematode dauer larva formation. Nature 290, 668-671. Abstract Article

Sambongi, Y., Nagae, T., Liu, Y., Yoshimizu, T., Takeda, K., Wada, Y., and Futai, M. (1999). Sensing of cadmium and copper ions by internally exposed ADL, ASE, and ASH neurons elicits avoidance response in Caenorhabditis elegans. Neuroreport 10, 753-757. Abstract

Sawin, E.R., Ranganathan, R., and Horvitz, H.R. (2000). C. elegans locomotory rate is modulated by the environment through a dopaminergic pathway and by experience through a serotonergic pathway. Neuron 26 , 619-631. Abstract Article

Schafer, J.C., Haycraft, C.J., Thomas, J.H., Yoder, B.K., and Swoboda, P. (2003). XBX-1 encodes a dynein light intermediate chain required for retrograde intraflagellar transport and cilia assembly in Caenorhabditis elegans. Mol. Biol. Cell 14, 2057-2070. Abstract Article

Schafer, J.C., Winkelbauer, M.E., Williams, C.L., Haycraft, C.J., Desmond, R.A., and Yoder, B.K. (2006). IFTA-2 is a conserved cilia protein involved in pathways regulating longevity and dauer formation in Caenorhabditis elegans. J. Cell Sci. 119, 4088-4100. Abstract Article

Scholey, J.M., Ou, G., Snow, J., and Gunnarson, A. (2004). Intraflagellar transport motors in Caenorhabditis elegans neurons. Biochem. Soc. Trans. 32:682-684. Abstract Article

Shakir, M.A., Fukushige, T., Yashuda, H., Miwa, J., and Siddiqui, S.S. (1993). C. elegans osm-3 gene mediating osmotic avoidance behavior encodes a kinesin-like protein. Neuroreport 4, 891-894. Abstract

Signor, D., Wedaman, K.P., Orozco, J.T., Dwyer, N.D., Bargmann, C.I., Rose, L.S., and Scholey, J.M. (1999a). Role of a class DHC1b dynein in retrograde transport of IFT motors and IFT raft particles along cilia, but not dendrites, in chemosensory neurons of living Caenorhabditis elegans. J. Cell Biol. 147, 519-530. Abstract Article

Signor, D., Wedaman, K.P., Rose, L.S., and Scholey, J.M. (1999b). Two heteromeric kinesin complexes in chemosensory neurons and sensory cilia of Caenorhabditis elegans. Mol. Biol. Cell 10, 345-360. Abstract

Smith, J.C., Northey, J.G., Garg, J., Pearlman, R.E., and Siu, K.W. (2005). Robust method for proteome analysis by MS/MS using an entire translated genome: demonstration on the ciliome of Tetrahymena thermophila. J. Proteome Res. 4, 909-919. Abstract Article

Smith, U.M., Consugar, M., Tee, L.J., McKee, B.M., Maina, E.N., Whelan, S., Morgan, N.V., Goranson, E., Gissen, P., Lilliquist, S., et al. (2006). The transmembrane protein meckelin (MKS3) is mutated in Meckel-Gruber syndrome and the wpk rat. Nat. Genet. 38, 191-196. Abstract Article 
Snow, J.J., Ou, G., Gunnarson, A.L., Walker, M.R., Zhou, H.M., Brust-Mascher, I., and Scholey, J.M. (2004). Two anterograde intraflagellar transport motors cooperate to build sensory cilia on C. elegans neurons. Nat. Cell Biol. 6, 1109-1113. Abstract Article

Starich, T.A., Herman, R.K., Kari, C.K., Yeh, W.H., Schackwitz, W.S., Schuyler, M.W., Collet, J., Thomas, J.H., and Riddle, D.L. (1995). Mutations affecting the chemosensory neurons of Caenorhabditis elegans. Genetics 139, 171-188. Abstract

Swoboda, P., Adler, H.T., and Thomas, J.H. (2000). The RFX-type transcription factor DAF-19 regulates sensory neuron cilium formation in C. elegans. Mol. Cell 5, 411-421. Abstract Article

Sulston, J.E., Albertson, D.G., and Thomson, J.N. (1980). The Caenorhabditis elegans male: postembryonic development of nongonadal structures. Dev. Biol. 78, 542-576. Abstract Article

Sulston, J., and Brenner, S. (1975). Dopaminergic neurons in the nematode Caenorhabditis elegans. J. Comp. Neurol. 163, 215-226. Abstract Article

Sun, Z., Amsterdam, A., Pazour, G.J., Cole, D.G., Miller, M.S., and Hopkins, N. (2004). A genetic screen in zebrafish identifies cilia genes as a principal cause of cystic kidney. Development 131, 4085-4093. Abstract Article

Tobin, D., Madsen, D., Kahn-Kirby, A., Peckol, E., Moulder, G., Barstead, R., Maricq, A., and Bargmann, C. (2002). Combinatorial expression of TRPV channel proteins defines their sensory functions and subcellular localizations in C. elegans neurons. Neuron 35, 307-318. Abstract Article

Uchida, O., Nakano, H., Koga, M., and Ohshima, Y. (2003). The C. elegans che-1 gene encodes a zinc finger transcription factor required for specification of the ASE chemosensory neurons. Development 130, 1215-1224. Abstract Article

Ward, S. (1973). Chemotaxis by the nematode Caenorhabditis elegans: identification of attractants and analysis of the response by use of mutants. Proc. Natl. Acad. Sci. U.S.A. 70, 817-821. Abstract Article

Ward, S., Thomson, N., White, J.G., and Brenner, S. (1975). Electron microscopical reconstruction of the anterior sensory anatomy of Caenorhabditis elegans. J. Comp. Neurol. 160, 313-337. Abstract Article

Ware, R.W., Clark, D., Crossland, K., and Russell, R.L. (1975). The nerve ring of the nematode Caenorhabditis elegans: sensory input and motor output. J. Comp. Neurol. 162, 71-110. Article

Webber, W.A., and Lee, J. (1975). Fine structure of mammalian renal cilia. Anat. Rec. 182, 339-343. Abstract Article

Wicks, S.R., de Vries, C.J., van Luenen, H.G., and Plasterk, R.H. (2000). CHE-3, a cytosolic dynein heavy chain, is required for sensory cilia structure and function in Caenorhabditis elegans. Dev. Biol. 221, 295-307. Abstract Article

Winkelbauer, M.E., Schafer, J.C., Haycraft, C.J., Swoboda, P., and Yoder, B.K. (2005). The C. elegans homologs of nephrocystin-1 and nephrocystin-2 are cilia transition zone proteins involved in chemosensory perception. J. Cell Sci. 118, 5575-5587. Abstract Article

Wittenburg, N., and Baumeister, R. (1999). Thermal avoidance in Caenorhabditis elegans: An approach to the study of nociception. Proc. Natl. Acad. Sci. U.S.A. 96, 10477-10482. Abstract Article

Wolf, M.T., Lee, J., Panther, F., Otto, E.A., Guan, K.L., and Hildebrandt, F. (2005). Expression and phenotype analysis of the nephrocystin-1 and nephrocystin-4 homologs in Caenorhabditis elegans. J. Am. Soc. Nephrol. 16, 676-687. Abstract Article

Yang, J., and Li, T. (2005). The ciliary rootlet interacts with kinesin light chains and may provide a scaffold for kinesin-1 vesicular cargos. Exp. Cell Res. 309, 379-389. Abstract Article 
Yang, J., Gao, J., Adamian, M., Wen, X., Pawlyk, B., Zhang, L., Sanderson, M.J., Zuo, J., Makino, C.L., and Li, T. (2005). The ciliary rootlet maintains long-term stability of sensory cilia. Mol. Cell Biol. 25, 4129-4137. Abstract Article

Yang, J., Liu, X., Yue, G., Adamian, M., Bulgakov, O., and Li, T. (2002). Rootletin, a novel coiled-coil protein, is a structural component of the ciliary rootlet. J. Cell Biol. 159, 431-440. Abstract Article

All WormBook content, except where otherwise noted, is licensed under a Creative 